\title{
From Principles to Rules: The Case for Statutory Rules Governing Aspects of Judicial Disqualification
}

Jula Hughes

Philip Bryden

Follow this and additional works at: http://digitalcommons.osgoode.yorku.ca/ohlj

Part of the Judges Commons

Article

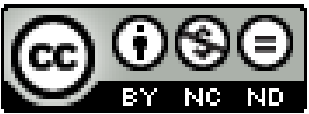

This work is licensed under a Creative Commons Attribution-Noncommercial-No Derivative Works 4.0 License.

\section{Citation Information}

Hughes, Jula and Bryden, Philip. "From Principles to Rules: The Case for Statutory Rules Governing Aspects of Judicial Disqualification." Osgoode Hall Law Journal 53.3 (2016) : 853-897.

http://digitalcommons.osgoode.yorku.ca/ohlj/vol53/iss3/4 


\title{
From Principles to Rules: The Case for Statutory Rules Governing Aspects of Judicial Disqualification
}

\begin{abstract}
The common law "reasonable apprehension of bias" test for judicial disqualification is highly fact- and contextspecific. While there are good reasons for this approach as a general proposition, it also gives rise to considerable uncertainty for both judges and litigants in considering whether or not it is appropriate for a judge to sit in a marginal case. This article explores statutory judicial disqualification regimes in the United States, Germany, and Quebec to gain insights into how statutory rules can be employed to provide greater clarity to judges and litigants who are addressing situations that have the potential to give rise to judicial disqualification. Using these insights, the authors then propose the use of statutory rules to address problem areas with respect to professional relationships with former colleagues and clients, prior judicial involvement with litigants, extrajudicial writings, and procedures for making determinations concerning judicial disqualification.
\end{abstract}

\section{Keywords}

Judges--Disqualification; United States; Germany; Québec (Province) 


\title{
From Principles to Rules: The Case for Statutory Rules Governing Aspects of Judicial Disqualification
}

\author{
JULA HUGHES AND PHILIP BRYDEN*
}

\begin{abstract}
The common law "reasonable apprehension of bias" test for judicial disqualification is highly fact- and context-specific. While there are good reasons for this approach as a general proposition, it also gives rise to considerable uncertainty for both judges and litigants in considering whether or not it is appropriate for a judge to sit in a marginal case. This article explores statutory judicial disqualification regimes in the United States, Germany, and Quebec to gain insights into how statutory rules can be employed to provide greater clarity to judges and litigants who are addressing situations that have the potential to give rise to judicial disqualification. Using these insights, the authors then propose the use of statutory rules to address problem areas with respect to professional relationships with former colleagues and clients, prior judicial involvement with litigants, extrajudicial writings, and procedures for making determinations concerning judicial disqualification.
\end{abstract}

L'épreuve de «crainte raisonnable de partialité » prévue par la common law pour nécessiter à un magistrat de se récuser repose fortement sur les faits et le contexte. Bien que cette approche soit généralement bien fondée, elle suscite tant chez les juges que chez les plaideurs une grande incertitude quand vient le temps de déterminer si un juge est habilité à siéger dans un cas douteux. Cet article examine le régime d'incapacité judiciaire prévu par la loi aux États-Unis, en Allemagne et au Québec afin de mieux comprendre comment les règles

* Jula Hughes is an Associate Professor of Law at the University of New Brunswick. Philip Bryden is a Professor of Law at the University of Alberta and is on leave as Deputy Minister, Alberta Justice and Solicitor General. The opinions expressed in this article are those of the authors and do not reflect the views of the Government of Alberta. Thank you to Ashley Godfrey, JD Candidate 2017, UNB, for her able research assistance. 
prévues par la loi peuvent clarifier tant au bénéfice des juges que des plaideurs les situations susceptibles d'entraîner une incapacité judiciaire. À partir de cela, les auteurs proposent le recours aux règles prévues par la loi pour résoudre les problèmes que pourraient entraîner des relations professionnelles avec d'anciens collègues ou clients, une implication juridique préalable avec les plaideurs, des écrits extrajudiciaires et les procédures susceptibles d'entraîner une incapacité judiciaire.

I. EMPIRICAL RESEARCH ON DIFFICULTIES IN APPLYING THE “REASONABLE

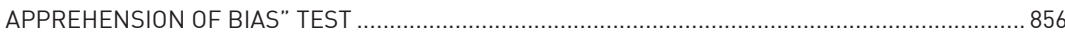

II. AN OVERVIEW OF AMERICAN LAW GOVERNING JUDICIAL DISQUALIFICATION …....................... 860

III. AN OVERVIEW OF GERMAN LAW GOVERNING JUDICIAL DISQUALIFICATION ............................. 867

IV. AN OVERVIEW OF JUDICIAL DISQUALIFICATION UNDER THE QUEBEC CODE OF CIVIL PROCEDURE

V. POTENTIAL RULE-BASED SOLUTIONS FOR DISQUALIFICATION ISSUES IN COMMON LAW

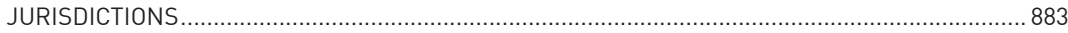

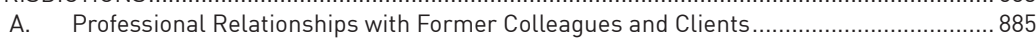

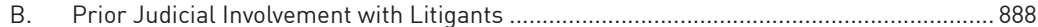

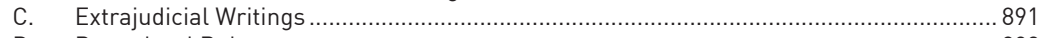

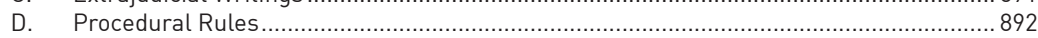

VI. CONCLUSION 896

COURTS IN SEVERAL COMMON LAW JURISDICTIONS have adopted one variation or another of a highly fact-driven and contextual "reasonable apprehension of bias" test for judicial disqualification. For example, the English Court of Appeal in the Locabail decision emphasized that "every application must be decided on the facts and circumstances of the individual case." Similarly, the Privy Council has asserted in a New Zealand case that " $[t]$ his is a corner of the law in which the context, and the particular circumstances, are of supreme importance." 2 The Supreme Court of Canada, drawing on these decisions, concluded in Wewaykum that "[a]s a result, it cannot be addressed through peremptory rules, and contrary to what was submitted during oral argument, there are no 'textbook' instances."

Despite this assertion by Canada's highest court, we argue in this article that statutory rules have a useful role to play in the law of judicial disqualification.

1. Locabail (UK) Ltd v Bayfield Properties Ltd, [1999] EWCA Civ 3004, [2000] QB 451 at para 480.

2. Man O'War Station Ltd v Auckland City Council (Judgment No 1), [2002] UKPC 28 at para 11, [2002] 3 NZLR 577 (PC).

3. Wewaykum Indian Band v Canada, 2003 SCC 45 at para 77, [2003] 2 SCR 259 [Wewaykum]. 
To advance this argument, we draw on the results of a study of the experiences and attitudes of Canadian provincial and territorial judges concerning recusal and disqualification ${ }^{4}$ to identify some of the difficulties judges experience in applying the fact-sensitive "reasonable apprehension of bias" test in marginal cases and some of the reasons for these difficulties. We then consider experiences in two countries, the United States and Germany, that have to a significant extent codified judicial disqualification. Further, we discuss the experience with statutory provisions governing judicial disqualification in the province of Quebec in particular. While these codifications typically include a general requirement that judges not sit on cases where their impartiality might reasonably be questioned, ${ }^{5}$ they often supplement these general provisions with more detailed rules governing disqualification based on certain facts that might give rise to a concern about impartiality. Of equal importance, they often contain rules identifying situations that do not, without more, result in a judge's disqualification.

In each of the comparator jurisdictions, we situate recusal rules within a broader constitutional and cultural context related to the role of the judiciary, though we limit the scope of the analysis to areas that might be helpful in considering specific recommendations for adaptation to the Canadian context outside of Quebec. We give an overview of the enumerated grounds of disqualification and consider the relationship between general grounds of disqualification and enumerated grounds. In short, in Germany and the United States, the enumerated grounds are grounds for automatic disqualification. In Quebec, only one of the enumerated grounds is a basis for automatic disqualification, though the other codified grounds will usually be sufficient to require disqualification despite the permissive statutory language. Lastly, we describe the procedural regime in each jurisdiction, with particular focus on the question of who decides recusal motions.

We suggest that there are at least three substantive areas where a rule-based approach to high-frequency bias issues is helpful: professional relationships between justice personnel and litigation participants; prior judicial consideration in a case or in related litigation; and extrajudicial writings suggesting a

4. Philip Bryden \& Jula Hughes, "The Tip of the Iceberg: A Survey of the Philosophy and Practice of Canadian Provincial and Territorial Judges Concerning Judicial Disqualification" (2011) 48 Alta L Rev 569 [Bryden \& Hughes, "Tip of the Iceberg”].

5. See e.g. 28 USC $\$ 455$ (a). It reads, "Any justice, judge or magistrate judge of the United States shall disqualify himself in any proceeding in which his impartiality might reasonably be questioned." See also Texas Rules of Civil Procedure 18b(b)(1). The rules state, "A judge must recuse in any proceeding in which: (1) the judge's impartiality might reasonably be questioned." 
predisposition. Additionally, and importantly, we suggest that procedural rules regarding recusal motions should be made explicit. ${ }^{6}$

\section{EMPIRICAL RESEARCH ON DIFFICULTIES IN APPLYING THE “REASONABLE APPREHENSION OF BIAS” TEST}

The empirical data for this article are drawn from our earlier study (conducted with the assistance of the Canadian Association of Provincial Court Judges) of Canadian provincial and territorial court judges' attitudes toward and experiences with recusal and disqualification. We surveyed 137 provincial and territorial judges. Our survey respondents included provincial court judges from each of the ten Canadian provinces and three territorial judges. The survey was in two parts. The first part of the survey asked questions about the type of jurisdiction the judges exercised, their personal experience with recusal, and their general expectations with respect to recusal in their jurisdiction. The second, and longer, part consisted of thirty-two scenarios where recusal might be appropriate and asked for the judges' views on these scenarios, which dealt with professional relationships, personal relationships, and prior knowledge derived from other judicial proceedings. We describe the methodology and results in detail elsewhere. ${ }^{7}$ Three findings from that earlier study are significant for present purposes. The first is that reported decisions significantly under-represent the incidence of recusal because most of the time judges recuse themselves of their own motion without formal process and without issuing reasons. Two-thirds of our survey respondents indicated that they recused themselves between one and five times in a typical year. Another 19 per cent reported that they recused themselves more than five times in a typical year, and only 14 per cent indicated that they would not recuse themselves at all in a typical year. More than half of the respondents (55 per cent) indicated that they recused themselves of their own motion more than 90 per cent of the time, and another 30 per cent reported that they did so between 50 per cent and 90 per cent of the time. Only 12 per cent indicated that they never recused themselves of their own motion. ${ }^{8}$ These findings are consistent with John Leubsdorf's observation that American jurisprudence on recusal and disqualification is weighted heavily in favour of decisions explaining why it was appropriate for the judge to sit because American judges are obliged to give

6. See Philip Bryden, "Legal Principles Governing the Disqualification of Judges" (2003) 82

Can Bar Rev 555 at 596.

7. Bryden \& Hughes, "Tip of the Iceberg," supra note 4.

8. Ibid, 576-77. 
written reasons for rejecting an application to disqualify themselves, whereas, those who do recuse themselves are not required to, and typically do not, give written reasons for doing so. ${ }^{9}$

The second finding that is significant for present purposes is that most of the survey respondents had a very weak sense of common practice concerning issues that are, in theory, governed by local tradition. In Canada, the "reasonable apprehension of bias" test is thought to potentially disqualify judges from hearing cases involving their former clients or involving lawyers with whom they previously practiced law. This is true even though the judge has no personal knowledge of the case from his or her time in practice and no close personal relationship with the lawyer from his or her former firm who is arguing the matter before the judge. The breadth of this prohibition is mitigated by what is described as a "cooling off period" after which the judge may hear cases involving former clients or involving lawyers with whom the judge practised. This cooling-off period applies absent other disqualifying circumstances, such as a close personal relationship with the lawyer or client or personal involvement with the matter prior to the judge's appointment to the bench. The Canadian Judicial Council's publication Ethical Principles for Judges offers the following advice:

With respect to the judge's former law partners, or associates and former clients, the traditional approach is to use a "cooling off period," often established by local tradition at 2, 3 or 5 years and in any event at least as long as there is any indebtedness between the firm and the judge .... ${ }^{10}$

Our survey asked if the courts in their jurisdiction had an accepted "cooling off period" after which it was appropriate for a judge to hear cases where the judge's former client is a party or the judge's former firm is representing a party. We asked separate questions regarding former law firm colleagues and former clients, and the majority of respondents answered that there was no accepted cooling-off period in either case. ${ }^{11}$ A minority of the judges in most jurisdictions answered "yes" to both questions, ${ }^{12}$ though the response that there was an accepted cooling-off period was stronger for former law firms than for former clients. ${ }^{13}$ Moreover, in some jurisdictions (Alberta, Newfoundland, and New Brunswick)

9. John Leubsdorf, "Theories of Judging and Judge Disqualification" (1987) 62 NYU L Rev 237 at 244-45.

10. Canadian Judicial Council, Ethical Principles for Judges (Ottawa: Canadian Judicial Council, 1998) at 52.

11. Bryden \& Hughes, "Tip of the Iceberg," supra note 4 at 602-603 (charts 8 and 9).

12. Ibid.

13. Ibid. 
the majority view was that there was an accepted cooling-off period for law firms, though not for clients. ${ }^{14}$

The final relevant finding from our survey is that the "reasonable apprehension of bias" test appears to give very limited guidance to judges in addressing relatively common but analytically marginal fact patterns. The facts are analytically marginal because judges encounter situations that may plausibly be argued to give rise to bias concerns, but the legal test for whether a reasonable apprehension of bias exists only marginally constrains the outcome of the analysis for whether the judge should recuse. This was evident from the high degree of variation in the responses to the thirty-two scenarios posed in the survey. Only for one scenario was there near-universal agreement (more than 90 per cent) on one of the four possible answers we offered to the question of whether or not the respondent would be recused. In another five scenarios there was clearly a dominant view, with 65 to 89 per cent of the respondents agreeing on a single answer. In another nine scenarios, between 50 per cent and 64 per cent of the respondents selected the most popular answer. On the other hand, in seventeen of the thirty-two scenarios, no single answer attracted the support of 50 per cent of the respondents. In eleven scenarios, the most popular answer attracted the support of between 40 per cent and 49 per cent of the respondents, and in the case of six scenarios, no single answer received the support of as many as 40 per cent of the respondents. ${ }^{15}$

Based on the survey, we proposed that the "reasonable apprehension of bias" test itself could be modified to give judges a better understanding of the rationale for trends in the jurisprudence that are otherwise difficult to comprehend and better tools with which to make decisions about whether or not to recuse themselves in marginal cases. ${ }^{16}$ Our objective here is similar: to make the law governing judicial disqualification more transparent and easier to apply consistently.

We take a relatively modest approach to statutory reform because we are of the view that the "reasonable apprehension of bias" test is basically sound and because we are not convinced that making judicial disqualification either substantially more difficult or (more likely, if the American discourse is any indicator) substantially easier would fundamentally alter the public perception

14. Ibid at 601-603.

15. Ibid at 579-80.

16. Jula Hughes \& Philip Bryden, "Refining the Reasonable Apprehension of Bias Test: Providing Judges Better Tools for Addressing Judicial Disqualification" (2013) 36 Dal L J 171 [Hughes \& Bryden, "Refining the Test"]. 
of the judicial system, at least in Canada. ${ }^{17}$ This is not to suggest that we believe that all segments of the Canadian public are equally satisfied with the Canadian judicial system or even that everyone who goes through a legal process in Canada is completely convinced of the judge's impartiality. Rather, our approach flows from the view that making laws that are designed to satisfy the public that judges are impartial represents only one element in a larger enterprise of satisfying the public that the judicial system is accessible, efficient, and responsive, and produces just results. ${ }^{18}$ The optimal point of balance between achieving this public satisfaction and providing litigants with reassurance about judicial impartiality is likely to be elusive, and in our view there are times when it is more productive to focus on the clarity and consistency of the rules governing judicial disqualification than on the precise content of the rules themselves.

17. In a fascinating study, James Gibson and Gregory Caldeira used a national survey of 1,092 Americans to explore the effects of campaign financing on their perceptions of judicial impartiality. They presented the survey respondents with a vignette drawn from the fact pattern in a recent US Supreme Court decision. See Caperton v AT Massey Coal Co, 556 US 868 (2009), 129 S Ct 2252 [Caperton]. They varied the basic fact pattern in a variety of ways to determine whether, and if so to what extent, the respondents' perceptions of the judge's impartiality and their overall perception of the impartiality of the justice system were altered in response to these variations. Variations included such things as whether or not the judge accepted a campaign contribution, whether and to what extent the contribution influenced the judge's electoral success, whether or not the judge recused, and whether or not the judge's vote influenced the outcome of the case in favour of the campaign contributor. James L. Gibson \& Gregory A. Caldeira, "Judicial Impartiality, Campaign Contributions, and Recusals: Results from a National Survey” (2013) $10 \mathrm{~J}$ Empirical Legal Studies 76. One of their key findings was that:

....recusals can do something to rescue the fairness of courts, but that recusal alone is insufficient to repair the damage created by a contributions-based perceived conflict of interest. Perhaps no one really expects that recusal is a perfect palliative for conflicts but now we have national evidence of the limits of that practice. We observe, however, that this experiment also discovers that recusal might succeed in boosting perceptions of fairness and impartiality to at least a marginally acceptable level (ibid at 96).

18. On the importance of these issues, see Action Committee on Access to Justice in Civil and Family Matters, Access to Civil and Family Justice, A Roadmap for Change (Ottawa: Action Committee on Access to Justice in Civil and Family Matters, 2013), online: <http://www. cfcj-fcjc.org/sites/default/files/docs/2013/AC_Report_English_Final.pdf>. 


\section{AN OVERVIEW OF AMERICAN LAW GOVERNING JUDICIAL DISQUALIFICATION}

In both Canada and the United States, judicial impartiality is a constitutionally protected right. ${ }^{19}$ The content of this right is informed by the common law in both jurisdictions, though American thinking is influenced by English common law as it existed prior to the American revolution, whereas Canadian law is influenced by English common law as it had evolved by the middle of the nineteenth century. In the United States, considerable discretion is left to Congress and state legislatures to determine the precise parameters of the law governing judicial disqualification..$^{20}$ Contemporary law governing judicial disqualification at both the federal and state level is significantly shaped by legislative action. The law in both countries begins with a presumption of judicial impartiality, but there are significant differences in terms of what is needed to displace the presumption of judicial impartiality in the absence of statutory intervention.

The Canadian constitution's commitment to judicial impartiality has been interpreted in a manner that is informed by the modern common law "reasonable apprehension of bias" test. ${ }^{21}$ Our courts have taken the view that, since it will usually be impossible to determine whether or not a judge is actually biased, the question is whether there are objective circumstances that would cause a

19. In Canada, this is made explicit for criminal trials in s 11(d) of the Canadian Charter of Rights and Freedoms. See Canadian Charter of Rights and Freedoms, Part I of the Constitution Act, 1982 being Schedule B to the Canada Act 1982 (UK), 1982, c 11, s 11(d). It reads, "Any person charged with an offence has the right ... (d) to be presumed innocent until proven guilty according to law in a fair and public hearing by an independent and impartial tribunal." The constitutional standard for judicial impartiality is the same as the common law "reasonable apprehension of bias" standard and is linked to broader concepts of judicial independence and fundamental justice. See $R v R D S$, [1997] 3 SCR 484 at para 31, 161 NSR (2d) 241 [RDS] (respecting the "reasonable apprehension of bias" standard); Reference re: Remuneration of Judges of the Provincial Court of PEI, [1997] 3 SCR 3 at paras 111-13, 156 Nfld \& PEIR 1 [Provincial Judges Reference] (respecting judicial independence); Ruffo $v$ Conseil de la Magistrature, [1995] 4 SCR 267 at para 38 (available on CanLii) (respecting fundamental justice); Pearlman v Manitoba Law Society Judicial Committee, [1991] 2 SCR 869, 84 DLR (4th) 105 (respecting fundamental justice). In the United States, the constitutional concern for judicial impartiality flows from judicial interpretation of the due process clauses of the Fifth and Fourteenth Amendments. See e.g. Caperton, supra note 17; Withrow v Larkin 421 US 35 (1975), 95 S Ct 1456.

20. See FTC $v$ Cement Institute, 333 US 683 at 702 (1948), 68 S Ct 793; Tumey v Ohio, 273 US 510 at 523 (1927), $47 \mathrm{~S}$ Ct 437.

21. See RDS, supra note 19 at paras 31, 46, 48-49; Provincial Judges Reference, supra note 19 at paras 111-13. 
reasonable person to believe that the judge was not impartial. ${ }^{22}$ The existence of objective circumstances that would cause a reasonable person to believe that, on balance, the judge would either consciously or unconsciously fail to decide the case fairly, is sufficient in Canada to displace the presumption of impartiality. Because common law and constitutional concepts of impartiality are essentially the same, judicial disqualification decisions in Canada are almost invariably made using common law standards. ${ }^{23}$

As noted above, American constitutional law governing judicial disqualification is influenced by pre-Revolutionary English common law, which took a restrictive approach to judicial disqualification and required disqualification only where the judge had a financial interest in the outcome of the dispute. ${ }^{24}$ Even though English common law was using a variation of the familiar "apprehension of bias" framework by the mid-nineteenth century, ${ }^{25}$ American courts did not modify the common law to adopt an "apprehension of bias" approach to judicial disqualification. The due process protections in the US Constitution have therefore been interpreted as preventing a probability of actual bias on the part of the judge, as opposed to guaranteeing that there will be no appearance that a judge might be biased. ${ }^{26}$

The evolution of American law of judicial disqualification has accordingly taken place primarily through federal and state statutes, though state constitutions and rules of court also contain rules expanding disqualification in circumstances beyond those required by the US Constitution. Federal and state statutes have

22. Wewaykum, supra note 3 at paras 66-67; RDS, supra note 19 at paras 31-49 (L'Heureux-Dubé and McLachlin JJ), 111-15 (Cory J).

23. As discussed in greater detail below, both arts 201-205 of the new Code of Civil Procedure (RLRQ c C-25.01) enacted by the Quebec National Assembly in 2014 and arts 234-42 of its predecessor, the Code of Civil Procedure (RSQ c C-25), set out rules governing the disqualification of Quebec judges in civil proceedings. Code of Civil Procedure, arts 201-205 CCP [New Code of Civil Procedure]; Code of Civil Procedure arts 234-42 CCP. Although this has not always been the case, in recent years the judicial disqualification provisions of the pre-2014 versions of the Code were interpreted in a manner that was designed to make them broadly consistent with the common law approach to judicial disqualification. See e.g. Dufour v 99516 Canada Inc, [2001] RJQ 1202 (available on QL) (QC CA) [Dufour].

24. See Caperton, supra note 17. See more generally, Richard Flamm, Judicial Disqualification, Recusal and Disqualification of Judges, 2d ed (Berkeley: Banks \& Jordan Law Publishing Co, 1997), ch 1 [Flamm, Judicial Disqualification]; Richard Flamm, "The History of Judicial Disqualification in America" (2013) 52 Judges' Journal 12.

25. See Dimes v Proprietors of Grand Junction Canal (1852), 3 HLC 759, 10 ER 301 (HL).

26. See Caperton, supra note 17; Raymond McKoski, "Disqualifying Judges When Their Impartiality Might Reasonably Be Questioned: Moving Beyond a Failed Standard” (2014) 56 Arizona L Rev 411 at 431-33 ["Disqualifying Judges"]. 
expanded disqualification using two different techniques, though these approaches are not mutually exclusive and some jurisdictions employ both. The first technique is to adopt a general requirement that judges must disqualify themselves in any proceeding "in which the judge's impartiality might reasonably be questioned," 27 supplemented by a series of more specific rules identifying instances in which a judge is disqualified. This approach is inspired by the 1972 ABA Model Code of Judicial Conduct (ABA Model Code), initially adopted by the ABA's House of Delegates in 1972 and subsequently modified in 1990, 2007, and 2010. The ABA Model Code is designed as a set of ethical principles governing the conduct and discipline of judges, but the provisions of what was originally Canon $3 \mathrm{E}$, now Rule 2.11, dealing with disqualification, were often incorporated directly or with some modification into statutes that gave parties rights to require judges to disqualify themselves in the circumstances enumerated by the statute. ${ }^{28}$ The second technique is to adopt what are described as "peremptory disqualification" rules, provisions that essentially allow a party to a proceeding to disqualify a judge simply by alleging that the judge has a bias against the party or in favour of a party adverse in interest. Peremptory disqualification provisions have often been interpreted restrictively by American courts, ${ }^{29}$ but a significant theme in contemporary American legal discourse is a debate over whether peremptory

27. See e.g. 28 USC $\$ 455$ (a) (1948).

28. See e.g. ibid, $\$ 455$.

29. For example, Richard Flamm argues persuasively that 28 USC $\$ 144$ was originally intended by Congress to create a peremptory disqualification regime for federal district court judges. Richard Flamm, Judicial Disqualification, supra note 24 . $\$ 144$ reads, in relevant part:

Whenever a party to any proceeding in a district court makes and files a timely and sufficient affidavit that a judge before whom the matter is pending has a personal bias or prejudice either against him or in favour of any adverse party, such judge shall proceed no further therein, but another judge shall be assigned to hear such proceeding.

When this provision was originally considered by the United States Supreme Court in Berger $v$ US, the Court concluded that the allegation in the affidavit had to be "legally sufficient" to warrant the disqualification of the judge, thereby transforming the provision into one that only required disqualification where there was just cause. Berger $v$ US (1921), 255 US 22, 55 S Ct 629. See also Debra Lyn Bassett \& Rex Perschbacher, "The Elusive Goal of Impartiality" (2011) 97 Iowa L Rev 181 at 211 ["Elusive Goal"]. 
disqualification should be expanded. ${ }^{30}$ American disqualification law at the state level also differs significantly from the law in common law jurisdictions such as Canada and England because it has to accommodate the fact that judges in many states are elected. As the cost of running successful judicial election campaigns has escalated, there has been considerable debate about whether current approaches to judicial disqualification in cases involving contributors to judicial election campaigns are adequate. ${ }^{31}$

For present purposes, it is more relevant to explore the detailed rules found in provisions that expand upon a general requirement of disqualification where impartiality might reasonably be questioned, than it is to discuss peremptory disqualification or judicial elections. Interesting as the peremptory disqualification and judicial election debates are, they have little resonance in the context of Canada and other comparable jurisdictions. Moreover, because the specific rules governing disqualification can be understood to represent specific examples of a more general requirement of disqualification wherever a judge's impartiality might reasonably be questioned, one can relatively easily imagine them inspiring rules that could supplement a more general "reasonable apprehension of bias" test for disqualification in Canada and other common law jurisdictions.

The main federal disqualification statute, 28 USC $\$ 455$ (and in particular, $\$ 455$ (b)-(f)), is a good example of this type of provision. 28 USC $\$ 455$ begins with a general prohibition in subsection 455(a) that states: "Any justice, judge, or magistrate judge of the United States shall disqualify himself in any proceeding in which his impartiality might reasonably be questioned." Subsection 455(b) begins with the statement that "[the judge] shall also disqualify himself in the following circumstances ...." As a result, subsection (b) puts in place a regime of automatic disqualification that does not require an inquiry into whether or not the circumstances would cause a reasonable person to question the judge's

30. See e.g. McKoski, "Disqualifying Judges," supra note 26; Charles Geyh, "Draft Report of the ABA Judicial Disqualification Project" (2008), online: <http://www.americanbar.org/content/ dam/aba/administrative/judicial_independence/jdp_geyh_report.authcheckdam.pdf $>$ at 60-65; James Sample \& Michael Young, "Invigorating Judicial Disqualification: Ten Potential Reforms" (2008) 92 Judicature 26 at 27-28; Debra Lyn Bassett, "Judicial Disqualification in the Federal Appellate Courts" (2002) 87 Iowa L Rev 1213 at 1224, 1251-1256.

31. See e.g. Bassett \& Perschbacher, "Elusive Goal," supra note 29; Christina Newton, "Interpreting Caperton: a Hybrid Solution to the Public Choice Problems of Judicial Elections” (2011) 8 J L Econ and Pol'y 143. 
impartiality. Subsection (b) has five clauses. The first requires disqualification where the judge has "a personal bias or prejudice concerning a party" or has "personal knowledge of disputed evidentiary facts concerning the proceeding." ${ }^{33}$ The second mandates disqualification where the judge, while in private practice, "served as a lawyer in the matter in controversy," where "a lawyer with whom [the judge] previously practiced law served during such association as a lawyer concerning the matter," and where the judge or a lawyer with whom the judge previously practised law "has been a material witness" concerning the proceeding. ${ }^{34}$ The third provides that the judge is disqualified where he or she "served in government employment and in such capacity participated as counsel, advisor or material witness concerning the proceeding or expressed an opinion concerning the merits of the particular case in controversy." ${ }^{35}$

It is worth pausing at this point to note that, although these provisions reflect themes that would be familiar to judges applying the "reasonable apprehension of bias" test for disqualification in Canada, they are both narrower and in some respects broader than the grounds for disqualification found in the Canadian jurisprudence. The second clause is narrower than Canadian disqualification practice in the sense that it only requires disqualification where the judge previously acted as a lawyer at an earlier stage in the same proceeding or where a member of the judge's former law firm acted in the proceeding while the judge was still associated with the firm. ${ }^{36}$ Canadian common law would generally regard the judge's association with the firm or with the client as a basis for disqualification

32. The common law in England and New Zealand draws a distinction between circumstances in which the judge's disqualification is automatic and those where disqualification is the result of a reasonable apprehension of bias. See $R v$ Bow Street Metropolitan Stipendiary Magistrate ex p Pinochet Ugarte (No 2), [2000] 1 AC 119, [1999] 1 All ER 577 HL (Eng); Porter v Magill, [2002] [2001] UKHL 67, 2 AC 357; Muir v Commissioner of Inland Revenue, [2007] NZCA 334, [2007] 3 NZLR 495; Saxmere Company Ltd $v$ Wool Board Disestablishment Co Ltd (No 1), [2009] NZSC 72, [2010] 1 NZLR 35, recalled [2009] NZSC 122, [2010] 1 NZLR 76. In Canada and Australia, the common law employs a unified reasonable apprehension of bias test to deal with all judicial disqualification cases. See Bryden \& Hughes, "Tip of the Iceberg," supra note 4; Ebner v The Official Trustee in Bankruptcy (2000), [2000] HCA 63, 176 ALR 644 [Ebner]. As a practical matter, Canadian and Australian courts would typically reach the same result as English and New Zealand courts in situations where automatic disqualification would be required, but they would do so using a "reasonable apprehension of bias" test. See Philip Bryden \& Jula Hughes, "Legal Principles Governing the Disqualification of Judges" (July 29, 2014) at 7-21, online: <http://ssrn.com/abstract=2473557>.

33. 28 USC, supra note $27, \$ 455(b)(1)$.

34. Ibid, $\$ 455(\mathrm{~b})(2)$.

35. Ibid, $\$ 455$ (b)(3).

36. Ibid, $\$ 455(\mathrm{~b})(2)$. 
for at least a period of time, whether or not the judge was involved with the matter

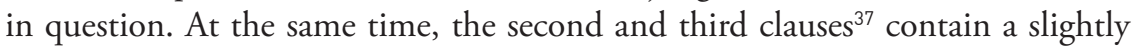
broader prohibition on judicial involvement in a matter than would be required by Canadian law in the sense that in Canada the passage of time is a relevant consideration for the purpose of deciding whether a judge is disqualified. ${ }^{38}$

The fourth clause deals with the judge's personal financial interests as well as those of his or her spouse or minor children residing in the judge's household, as well as "any other interest that could be substantially affected by the outcome of the proceeding." ${ }^{39}$ The statute includes an elaborate definition of financial interest that not only defines what will be regarded as a financial interest but also excludes certain types of interests from the definition. ${ }^{40}$ "Ownership in a mutual or common investment fund that holds securities," for example, "is not a 'financial interest' in such securities unless the judge participates in the management of the fund." 41 As a result, this automatic disqualification clause treats financial interests in a way that is substantially similar to, if not necessarily identical to, the way they would be treated under Canadian law, but gives much greater clarity and more specific guidance than one would find in Canadian law. ${ }^{42}$

The fifth automatic disqualification clause applies where a member of the judge's family is a party, is acting as a lawyer in the proceeding, "is known by the judge to have an interest that could be substantially affected by the outcome of the proceeding," or is "to the judge's knowledge likely to be a material witness in the proceeding." ${ }^{33}$ Once again, Canadian practice concerning judicial disqualification on the basis of family relationship would produce substantially similar, if not necessarily identical, results to this provision. ${ }^{44}$

37. Ibid, $\$ 455(\mathrm{~b})(2)-(3)$.

38. Canadian Judicial Council, supra note 10 at 52.

39. 28 USC, supra note $27, \$ 455(\mathrm{~b})(4)$.

40. Ibid, $\$ 455(\mathrm{~d})(4)$.

41. Ibid, $\$ 455(\mathrm{~d})(4)(\mathrm{i})$.

42. Ibid, $\$ 455(\mathrm{~b})(4)$. As the Supreme Court of Canada observed in the Wewaykum case, Canadian common law does not use the concept of automatic disqualification, and all types of disqualification, including ones based on the judge's financial interest in the outcome, are decided on the basis of a "reasonable apprehension of bias" test. Wewaykum, supra note 3 at paras 72-73. On the other hand, the application of that test will normally result in Canadian judges being disqualified where they have a direct and material financial interest in the outcome of the case before them. See Canadian Judicial Council, supra note 10 at 45-46 (paras 6.E.5-6.E.7).

43. Ibid, $\$ 455(\mathrm{~b})(5)$.

44. See Canadian Judicial Council, supra note 10 at $44-46$ (paras 6.E.3-6.E.7). 
Finally, subsections (e) and (f) explicitly address the issue of waiver by the parties. ${ }^{45}$ Waiver is not permitted in relation to the grounds of disqualification enumerated in subsection 455 (b), but it is allowed where disqualification arises under the more general provisions of subsection 455(a) "provided it is preceded by full disclosure on the record of the basis for disqualification." 46 Outside of Quebec, Canadian law governing waiver does not appear to draw any distinctions concerning the circumstances in which parties can waive disqualification, but there is a right to be fully informed of the relevant facts before the waiver doctrine will be applied. ${ }^{47}$

While the ABA Model Code represents the dominant model for state laws governing judicial disqualification, there is considerable variation in matters of detail even among states that follow it. To take just one example, clause 170.1(2) (B) of the California Code of Civil Procedure adopts a disqualification rule that is similar to Canadian practice with respect to a judge's former colleagues in legal practice and former clients. ${ }^{48}$ After partially adopting the ABA Model Code by indicating in clause $2(\mathrm{~A})$ that a judge is disqualified if he or she "served as a lawyer in the proceeding," the California statute states:

B. A judge shall be deemed to have served as a lawyer in the proceeding if within the past two years:

i. A party to the proceeding or an officer, director, or trustee of a party was a client the judge when the judge was in the private practice of law or a client of a lawyer with whom the judge was associated in the private practice of law.

ii. A lawyer in the proceeding was associated in the private practice of law.

This provision creates a presumptive rule of disqualification from the adjudication of cases involving former colleagues or personal or law firm clients during a two-year cooling-off period, while leaving in place a longer period of

45. Ibid, $\$ 455(\mathrm{e})-(\mathrm{f})$

46. Ibid, $\$ 455$ (a)-(b).

47. See Lambert v Lacey-House, 2013 NBCA 48 at paras 7, 19-21, 206 NBR (2d) 346 [Lambert]. For the situation in Quebec, see the discussion below of art 242 of Quebec's former Code of Civil Procedure. Code of Civil Procedure, art 242 CCP.

48. 48 California Code of Civil Procedure, cl 170.1(a)(2)(B). 
disqualification if the judge was personally involved as a lawyer in some aspect of the proceeding. ${ }^{49}$

American law governing the procedure for judicial disqualification varies from jurisdiction to jurisdiction. ${ }^{50}$ In many instances, judges will recuse themselves of their own motion, especially if it is evident that they fall within one of the enumerated grounds upon which disqualification is required. Some American jurisdictions have specific rules governing the procedures to be used by a party who seeks the disqualification of a judge who does not recuse himself or herself voluntarily, and in other jurisdictions the ordinary rules governing motion practice apply. ${ }^{51}$ Typically the judge whose disqualification is sought decides the motion, and in some jurisdictions the challenged judge has an affirmative obligation to do so. ${ }^{52}$ In other jurisdictions, the judge whose disqualification is sought has the discretion to transfer the decision to another judge, but this discretion is not commonly exercised. ${ }^{53}$ There are some jurisdictions where a judge who receives a motion seeking his or her recusal has the option of deciding to recuse himself or herself, but if that option is not taken, the decision on whether or not the judge is disqualified must be referred to another judge. ${ }^{54}$

\section{AN OVERVIEW OF GERMAN LAW GOVERNING JUDICIAL DISQUALIFICATION}

As in Canada, the guarantee of impartial adjudication in Germany is thought to have constitutional dimensions. However, the Basic Law does not expressly grant a specific right to an impartial tribunal. The jurisprudence instead anchors the right in two sections of the Basic Law: the general principle of the rule of law

49. Clause $170.1(\mathrm{a})(2)(\mathrm{C})$ creates a comparable presumption for any judge who "served as a lawyer for or officer of a public agency that is a party" to a proceeding. In this instance, the judge is presumed to have served as a lawyer in the proceeding "if he or she personally advised or in any way represented the public agency concerning the factual or legal issues in the proceeding." Ibid, cl 170.1(a)(2)(C).

50. Flamm, Judicial Disqualification, supra note 24, ch 17.

51. Ibid, $\$ 17.2$.

52. Ibid, $\$ 17.6$ at 499 .

53. Ibid, $\$ 17.6$ at $501-502$.

54. Ibid, $\$ 17.6$ at 502. See e.g. Texas Rules of Civil Procedure, Rule 18a, ss (f)-(g). 
(Rechtsstaatsprinzip) in article $20,{ }^{55}$ and the right to a lawful judge in article $101 .{ }^{56}$ The latter clause introduces the notion of a lawful judge (gesetzlicher Richter). ${ }^{57}$ At its core, this right protects against secret, ad hoc, or otherwise unchecked appointments of tribunals for specific purposes. In Canadian terms, it seems to be most closely related to the right of access to a court of inherent jurisdiction.

In the jurisprudence of Germany's Federal Constitutional Court (Constitutional Court), the right to a lawful judge has been amplified to give content to the notion that lawfulness includes impartiality. The right to one's lawful judge has a negative and a positive dimension: the negative right not to be subjected to a judge who is tainted by bias and the positive right to adjudication of the case before the court by the assigned judge absent a well-founded bias concern. The latter right strongly implies a duty to sit. Judicial independence is separately guaranteed in article $97 .{ }^{58}$ In criminal cases, courts have also resorted to the right to free choice of counsel in some recusal situations. ${ }^{59}$

German federal law codifies judicial disqualification in the various rules of court found in the courts' enabling statutes. The constitutional, criminal, and civil courts have structurally similar rules, but categories of automatic disqualification are tailored to the jurisdictional subject matter of the respective courts. Also, as the time of enactment varies, so does the actual wording. Various administrative courts of specialized jurisdiction incorporate the civil code model by reference. ${ }^{60}$ Compared to its Canadian counterpart, German law favours a duty to sit, both substantively (by requiring judges to sit in some situations where a Canadian judge would likely recuse) and procedurally (by ensuring that judges are not able to bow out easily or unnecessarily). At the same time, by providing

55. The legislature shall be bound by the constitutional order, the executive, and the judiciary by law and justice. Basic Law for the Federal Republic of Germany, online: <https://www. gesetze-im-internet.de/englisch_gg/> [Basic Law].

56. Klaus Schreiber, "ZR - Ausschließung und Ablehnung des Richters im Zivilprozess" (2011) 33:10 JURA - Juristische Ausbildung 745; ibid. Art 101 (1)(2) provides: "No one may be removed from the jurisdiction of his lawful judge."

57. Christoph Sowada, Der gesetzliche Richter im Strafverfahren (Berlin: Walter de Gruyter, 2002).

58. Basic Law, supra note 55, art 97.

59. German Code of Criminal Procedure [StPO], s 137(1), online: <http://www. gesetze-im-internet.de/englisch_stpo/> (official English translation by Brian Duffett and Monika Ebinger, updated translation by Kathleen Müller-Rostin) [StPO].

60. $\$ 54$ Abs 1 VwGO; Alexander Ignor, "Befangenheit im Prozess" (2012) 5 Zeitschrift für Internationale Strafrechtsdogmatik 228 at 230. Note that administrative courts are not equivalent to Canadian administrative tribunals as judges rather than tribunal members sit on these courts. 
grounds for automatic disqualification, the statutes introduce bright-line rules for some high-frequency situations.

The statutory rules regarding disqualification proceed in two parts. First, they set out situations that automatically disqualify a judge from hearing a case. Second, they provide for recusal motions by a litigant or a judge where a fear of bias exists or where a judge attempts to sit in a situation of automatic disqualification. In the case of the Constitutional Court, the statute additionally narrows the categories of automatic disqualification by excluding certain subcategories from the application of the more general principles.

Statutes also provide for procedural issues including who decides the issue, waiver, replacement procedures, and appellate remedies. These are potentially of significant interest to Canadian courts, which have typically developed their recusal procedures ad hoc.

While there is some variation in language, criminal, civil, and constitutional courts all contemplate automatic disqualification for substantially the same reasons: (1) Involvement by the judge or a close family member in the litigation as a litigant or witness or, in the case of criminal courts, as victim; ${ }^{61}$ (2) prior professional involvement in the matter as counsel or police officer; and (3) prior judicial involvement.

Despite these commonalities, there are important differences among the courts, particularly as they relate to the first and third categories. As regards the first category, personal involvement, the Constitutional Court Act excludes family status, occupation, ethnic origin, political party membership, and analogous grounds as constituting personal involvement. ${ }^{62}$

As regards the third category, in criminal courts, the part of the criminal procedure rules dealing with recusal would not appear to bar the participation of a trial judge in a new trial but merely in the (appellate) decision to order a new trial. However, section 354(2) of the German Code of Criminal Procedure (StPO) precludes remittal to the trial judge following a successful appeal. It requires a different chamber of the lower court to hear the new trial. ${ }^{63}$ Thus, unlike in Canada, it is not open to the appellate court to remit a matter to the trial judge

61. In all cases, a close family member is defined as related by blood to the third degree or by marriage to the second degree.

62. 62 Federal Constitutional Court Act [BVerfGG]), $\$ 18$ (translation by the Court available online: <http://www.bundesverfassungsgericht.de/SharedDocs/Downloads/EN/Gesetze/ BVerfGG.pdf?_blob=publicationFile\&v=1>).

63. StPO, supra note 59. 
for determination in light of the appellate decision. ${ }^{64}$ This represents a different weighing of two competing objectives: Avoiding the possible perception of a closed mind is preferred in the German context, while in the Canadian context, efficiency and judicial resource management tip the balance in favour of a power to remit.

In civil courts, there are three grounds related to prior judicial involvement that give rise to automatic disqualification: (1) prior involvement in the final adjudication of a matter; (2) prior involvement in a matter in which undue delay is alleged; and (3) prior judicial involvement in mediation or other alternative dispute resolution measures related to a particular matter.

In an interesting variation on the theme, the Constitutional Court Act also disqualifies judges who have had prior judicial involvement by reason of their office or profession but goes on to limit the scope of this ground of disqualification in two important ways. First, it excludes prior involvement in the legislative process as constituting disqualifying prior involvement, and second, it excludes as a disqualifying ground the articulation of an academic opinion in relation to a legal question of relevance to the proceeding.

In addition to automatic disqualification, a party may move for the recusal of a judge in all courts for two reasons: one, because of a fear of bias, and two, because a judge chose to sit despite the presence of automatic disqualification grounds. The test for a fear of bias is whether, based on a reasoned apprehension of the facts as they are known to it, the objecting party has cause to believe that the judge will adopt an inner stance towards the party that may interfere negatively with his or her impartiality or open mind.$^{65}$ Courts have emphasized that the question of judicial disqualification should be analyzed based on the knowledge of the litigant rather than that of a legal insider. ${ }^{66}$

Generally, the jurisprudence is concerned with situations giving rise to a fear of bias and, in particular, with the relationship between the enumerated grounds of automatic disqualification and arguable analogous grounds that might give rise to a fear of bias. The statutory rules are not exhaustive. One area that gives rise to bias motions in civil courts is that of personal relationships not covered by the automatic disqualification rules. Herbert Taubner suggests a categorization of the case law relating to personal bias into five classes: family

64. Gunther Arzt, Der befangene Strafrichter: Zugleich eine Kritik an der Beschränkung der Befangenheit auf die Parteilichkeit (Tübingen: Mohr Siebeck, 1969) at 1.

65. Gunter Widmaier \& Stephan Barton, Münchener Anwaltshandbuch Strafverteidigung, (Beck-Online: CH Beck, 2006) at para 73.

66. BGH (1988) StV 88, 417; BGH (1968) NJW 68, 710; ibid at para 73. 
relationships, memberships in clubs or corporations, acceptance of favours, personal relationships with professional litigation participants other than lawyers, and personal relationships with lawyers. ${ }^{67}$

Civil courts have found that a broader range of family and personal relationships may give rise to a reasonable apprehension of bias than merely those covered by the automatic disqualification rules. Family relations and other personal relationships warranting recusal include engagements, close friendships, personal antagonism, paternity or maternity of a child or having a child in common, and love affairs. On the other hand, the jurisprudence is clear in limiting this extension: Absent additional considerations, siblings-in-law (and similar family and social relationships that are not close or not current) and professional encounters (e.g., a builder or tradesperson doing work at the judge's house) do not give rise to a reasonable apprehension of bias. The literature is split on whether the relationship has to be direct or includes relationships with the judge's spouse. ${ }^{68}$

Memberships in organizations warrant recusal only if a club is very small, the judge has a leadership role, and the club is directly involved in litigation. Since judges, like all other citizens, have a constitutional right to be a member of a political party, such membership is never a reason to recuse.

The legislature has taken a slightly different and narrower approach to disqualifying personal relationships in criminal courts. While a criminal court judge is automatically disqualified where the alleged victim is his or her spouse, the prosecutor-spouse is not included in the list of automatic disqualification relationships. Some commentators have argued that a judge should not preside over a trial where her spouse is the prosecutor. This argument is at variance with jurisprudence of the Constitutional Court suggesting that in the absence of disqualification language, a personal relationship with the prosecutor is not in itself a basis for recusal. ${ }^{69}$ Further, the legislative choice permitting judges to sit when they have a close personal relationship with the prosecutor is clear.

67. Herbert Taubner, Der befangene Zivilrichter (Konstanz: Hartung-Gorre, 2005).

68. Ibid, citing Christian Stemmler, Befangenheit im Richteramt: eine systematische Darstellung der Ausschliessungs- und Ablehnungsgründe unter Berücksichtigung des gesetzlichen Richters als materielles Prinzip (PhD Dissertation, University of Tübingen, 1975) (favouring the narrower view); Taubner, ibid, citing Herbert Pabst v. Ohain, Die Ablehnung eines Richters wegen Besorgnis der Befangenheit aus politischen Gründen (PhD Dissertation, University of Freiburg, 1932) (for the broader view).

69. Klaus Ellbogen \& Felix Schneider, "Besorgnis der Befangenheit bei Ehe zwischen Richterin und Staatsanwalt" (2012) 5 Juristische Rundschau 188. 
As in other institutional design choices, there are competing values at stake here. The appearance of impartiality from the perspective of the accused will likely be affected when the judge is married to the prosecutor. On the other hand, judge-prosecutor marriages are very commonplace, and recusal on that basis would affect a large number of docketing decisions, particularly in small towns. ${ }^{70}$ The Federal Court of Justice (Bundesgerichtshof, BGH) has recently ruled in a civil context that recusal is warranted where the judge is married to someone in the same law firm as counsel in the case before the court, even where there is no evidence that the lawyer-spouse and the judge had discussed the file or that the lawyer-spouse's financial interests were significantly affected. ${ }^{71}$ In this case, the judge was married to a lawyer who practiced in the same law firm as respondent counsel. Since that decision was grounded in constitutional considerations, it may well be that the criminal court jurisprudence will follow suit.

This situation will be familiar to Canadian judges, as are prior professional relationships between judges and lawyers. Indeed, one of the areas of judicial disqualification with significant difficulties in Canada concerns the question whether and when professional relationships give rise to a reasonable apprehension of bias. The issue arises with frequency because Canadian judges are typically appointed from the practising bar and tend to have a well-established set of relationships with fellow lawyers at the time of their appointment. This problem arises less frequently in Germany because most judges are appointed as full-time judges immediately following their law studies and a brief period of clerkship (frequently served in courts or prosecution offices). ${ }^{72}$ There are two significant exceptions: The first is that a full professor of law is entitled to

70. American law typically reaches the opposite conclusion in the balancing of these concerns. At the federal level, judges are prohibited from sitting in cases where a spouse is acting as counsel. See 28 USC, supra note 27, $\$ 455(b)(5)$. In Florida, the Code of Judicial Conduct provides that

[a] judge shall disqualify himself or herself ... where the judge or the judge's spouse, or a person within the third degree of relationship to either of them, or the spouse of such a person: is a party to the proceeding, or an officer, director, or trustee of a party; ... a lawyer in the proceeding; is known by the judge to have a more than de minimis interest that could be substantially affected by the proceeding; [or] is to the judge's knowledge likely to be a material witness in the proceeding" [emphasis added].

Canon 3(E)(1)(d).

71. (2012) V ZB 102/11 (BGH 5th Zivilsenat) (Germany). See Katrin Dittert, "Richterablehnung wegen Tätigkeit dessen Ehegatten in der von der Gegenseite beauftragten Rechtsanwaltskanzlei” (2012) 15 jurisPR-MietR note 5.

72. Keith R. Fisher, "Education for Judicial Aspirants" (2011) 31 J Nat'l Ass'n Admin L Judiciary 99 at 115 (reprinted). 
hold part-time judicial office, and the second is that the appointment practice of the Constitutional Court, as discussed below in more detail, routinely sees limited-term appointments from the public law professoriate. It is thus not surprising that some of the most contentious cases regarding recusal in response to professional relationships arise in the Constitutional Court.

One of the most controversial recusal decisions of the Constitutional Court involved a politician who was a member of a law firm with which one of the judges of the Court was associated..$^{73}$ The Federal Minister of the Interior had allegedly accepted donations in contravention of the country's party financing laws. Justice Jentsch gave notice to his judicial colleagues of facts that might require recusal. ${ }^{74}$ In a split decision, four judges of the Court ruled that there was no reasonable apprehension of bias since mere membership in a political party was not a cause for recusal and Justice Jentsch could not be said to have a direct interest in the outcome of the litigation. ${ }^{75}$ This was the result because Justice Jentsch's membership in the firm had been suspended by operation of law during his tenure on the court and despite the fact that the law firm's name continued to include both his own name and Minister Kanther's.

When a related matter came to the Court in 2003, Justice Jentsch again gave notice of a potential apprehension of bias. He repeated his explanation about the membership of Mr. Kanther and his ongoing relationship with the law firm. This time, a unanimous Constitutional Court found that Justice Jentsch's relationship with Mr. Kanther did give rise to a reasonable apprehension of bias and that he should not sit. The Court distinguished its earlier decision on the basis that the prior review had taken place in the context of an abstract judicial review whereas

73. The jurisprudence of the Constitutional Court in this regard has a prominent and unusual commentator. In 2000, former Chief Justice Benda, who had led the Court until 1983, published a paper in which he criticized, with some venom, the recusal practice of his former Court. In it, he argued that the Constitutional Court applied too strong a presumption of impartiality, in part out of elitism or arrogance (asserting that a judge of the highest court is presumed to be of such high calibre, intellectually and morally, to make bias a virtual impossibility) and in part out of excessive collegial courtesy (noting that both in cases of applications and in cases of self-disclosure, it is the judicial colleagues of the impugned judge who adjudicate the motion). See Ernst Benda, "Befangenes zur Befangenheit" (2000) NJW 3620.

74. He was a founding partner in a law firm that now, with his consent, included the minister He noted that his membership in the firm had been suspended for the duration of his tenure on the Court by virtue of $\$ 104$ of the Constitutional Court Act. BverfGG, supra note 62, $\$$ 104. He also advised his colleagues that he no longer participated in the financial, revenue, and governance decisions of the firm except in fundamental matters of membership.

75. (2000) BVerfGE 102, 192 (Fed Const Ct) (Germany). 
the current case involved a closer connection between the allegations and Mr. Kanther. Thus, the personal reputation of Mr. Kanther and, by implication, the personal connection between him and the judge, were now squarely in issue. An adverse finding of the Court against Mr. Kanther might implicate him in further proceedings and affect the interests of the law firm. The Court affirmed the general presumption that a judge of the Constitutional Court possesses the necessary independence and distance to enable him or her to act impartially and objectively but noted that the legislative scheme was designed to address what it called the "evil appearance" (böser Schein) of a possible lack of impartiality. ${ }^{76}$ Upon reasonable appreciation of all of the circumstances, it therefore concluded that there was sufficient cause to doubt the impartiality of the judge because of his partnership with Mr. Kanther in the law firm. ${ }^{77}$ The difficulty encountered by the German court illustrates the usefulness of cooling-off periods adopted in the Canadian context and also highlights the importance of clear guidance for judges on post-retirement professional activities.

Another area where the Canadian and German experiences are structurally different but mutually illuminating is in their approaches to prior judicial involvement. A common source of applications for recusal in criminal cases is communications between the judge or presiding judge and one party. German law does not permit plea bargaining except under the direct supervision of the courts. Preparatory communications by the judge with one side lead to bias concerns in that the resulting 'deal' indicates a closed mind on the part of the judge. ${ }^{78}$ The federal parliament has now acted to regulate such communications ${ }^{79}$ and the Constitutional Court has held that only communications specifically authorized by the Act are permitted, precluding informal arrangements. ${ }^{80}$ While the problem is tied to the peculiarities of German procedural law, the solution might have application in Canada. High-frequency bias problems may be subject to legislative bright-line solutions. This would support arguments we have made elsewhere on, for example, breach hearings. ${ }^{81}$

The question of how much assistance a judge may provide to a self-represented litigant before crossing the line into apparent partiality raised novel bias issues

76. BVerfGE 108, 122 (Fed Const Ct) (Germany).

77. Ibid at paras 24-26.

78. (2007) 5 StR 227/07 (BGH, 5th Strafsenat) (Germany).

79. Gesetz zur Regelung der Verständigung im Strafverfahren vom 29. Juli 2009 (BGBl S. 2353)

[Regulation of Communications in Criminal Proceedings Act, July 29, 2009].

80. (2013) BVerfGe, 2 BvR 2628/10 (Fed Const Ct) (Germany).

81. Hughes \& Bryden, "Refining the Test," supra note 16 at 191. 
in German civil courts, as has been the case in the United States ${ }^{82}$ and, more recently, in Canada. ${ }^{83}$ The Code of Civil Procedure was amended in 2004 to require judges to play a more active case management role. This also means that they now provide more assistance to parties than previously thought appropriate in the generally adversarial system of civil justice in Germany. Gunnar Sticken argues that the novel obligations on judges to explain, inform, and prevent surprises may all operate to threaten judicial neutrality. ${ }^{84}$ Four situations are thought to give rise to concerns: (1) the judge directs a change in the pleadings; (2) the judge advises a party of an impending limitation period; (3) the judge is possibly obligated to explain the evaluation of evidence prior to rendering judgment; and (4) the party is or is not represented (does either scenario make a difference to the judicial obligation to advise?).

Sticken contends that neutrality requires that the judge not pursue "purposes" of his or her own as the adversarial nature of the proceedings is a necessary guarantor of impartiality. However, he accepts that promoting settlement does not undermine the impartiality of the judicial officer. ${ }^{85}$ Further, he concludes that the scope of the legislative change is modest and consistent with impartiality requirements. In his view, the new provisions do not require a judge to direct changes in pleadings or notify parties of a limitation period. ${ }^{86}$

On the other side of the coin, whether hostility between a judge and counsel is a reason to recuse is a complex question. The jurisprudence consistently holds that the hostility must spill over into hostility against the party, not merely the lawyer, and that the expression of such hostility must occur in the proceeding in which recusal is sought.

As in Canada, the expression of support, hostility, or any other views in a judicial capacity is dealt with distinctly from the question of any expression of views in an extra-judicial capacity. The statutory regime of the Constitutional Court Act contemplates exceptions to situations of automatic disqualification, several of which relate to the expression of views in an extrajudicial capacity.

82. Jona Goldschmidt, "How Are Courts Handling Pro Se Litigants" (1998-1999) 82 Judicature 13.

83. Richard Devlin, C Adèle Kent \& Susan Lightstone, "The Past, Present ... and Future(?) of Judicial Ethics Education in Canada" (2013) 16 Legal Ethics 1; Jona Goldschmidt, "Judicial Assistance to Self-represented Litigants: Lessons from the Canadian Experience" (2008-2009) 17 Mich St U Coll L J Int'l L 601.

84. Gunnar Sticken, Die 'neue' materielle Prozeßleitung (\$139 ZPO) und die Unparteilichkeit des Richters (Köln Berlin München: Carl Heymanns Verlag, 2004).

85. Ibid at 187.

86. Ibid at $185-90$. 
The question about the scope of these exceptions is framed as exploring the relationship between cases of automatic disqualification and those warranting recusal on a case-by-case basis. For example, given the express terms of Article $18,{ }^{87}$ direct involvement in the legislative process does not disqualify a judge. Could advice given by a judge to government in a professional capacity ever give rise to a reasonable apprehension of bias? The current jurisprudence of both chambers of the Constitutional Court uses a "without more" test. Under this approach, the mere fact that a judge has previously come into contact with or has articulated views on a matter is never sufficient, without more, to justify disqualification. The rules of when certain additional facts are sufficient to unseat the very strong presumption in favour of a duty to sit are being developed on a case-by-case basis.

Another statutory exception to automatic disqualification relates to the expression of views in academic writing that might otherwise be thought to indicate a bias. ${ }^{88}$ Interestingly, the exception for academic writing is itself the result of a recusal decision by the Constitutional Court. The 1966 Leibholz decision involved a challenge to legislation that established state-sponsored party financing. Leibholz was a professor of law at Göttingen and Bruge. He had served on the Constitutional Court for fifteen years. Between the oral hearing and the release of the judgment, he presented a paper at a constitutional law conference in which he indicated a preference for state party financing. Upon application by two fringe parties, the Court decided to disqualify Leibholz. In its decision, the Court indicated that the issue was not actual partiality but a "concern about partiality" (Besorgnis der Befangenheit). It stated that the test was whether a person without involvement in the process, in a reasonable manner appreciating the entire context, would have cause to doubt the impartiality and objective stance of the judge. ${ }^{89}$ The legislature disagreed with the conclusion of the Court and responded to the ruling by adding an academic writing exception into Article 18 .

87. BverfGG, supra note $62, \$ 18(2)$ (3) ("Involvement for the purposes of section 1 no. 2 shall not include ... participating in the legislative procedure ....").

88. This issue is peculiar to the German context. The public law professoriate has been a primary recruitment ground for judges on the Constitutional Court. Leading constitutional scholars make up the vast majority of appointees. Since appointments are presently subject to a non-renewable twelve-year term, the professorial appointment may bracket the judicial one. While judges do not teach during their judicial tenure, they frequently continue to participate in academic life including presenting at conferences. As a result, it is very common that judges would comment on any number of constitutional issues, many of which might come before the court during their tenure there.

89. BVerfGE 20,26 (Fed Const Ct) (Germany). 
In addition to statutory rules for automatic disqualification and express rules for situations that do not warrant recusal, a third element common to all three statutory schemes that might be useful to consider in the Canadian context is a set of procedural provisions. These provisions address issues such as limitation periods and waivers, how to bring recusal motions, determining who hears the motion, and delineating appeal and self-disqualification processes. Generally, an application for recusal must be brought early in the proceeding: In civil court, the motion must be brought before the moving party makes its first appearance; in the Constitutional Court, prior to the oral hearing on the merits; and in criminal court, prior to the examination of the first defence witness. Early motions are facilitated by permitting a request for naming judges and lay adjudicators prior to trial. ${ }^{90}$

The application must be brought in the court seized of the matter and is typically heard by a panel of that court, in most circumstances excluding the judge in relation to whom the application is brought. Where the issue arises because a judge formally identifies a reason that might give rise to a reasonable apprehension of bias, in most circumstances the recusal motion is also heard by a panel of the same court excluding the judge. A notable exception to the rule that a panel of the same court excluding the judge will hear the recusal motion can be found in the criminal rules of procedure. The trial judge himself or herself may determine whether the application is timely and, if appropriate, dismiss it for that reason. A panel not including the trial judge decides all other recusal motions. Dismissing a recusal motion on the basis of a finding that it was brought for purely tactical reasons has to be made by a unanimous panel, again excluding the trial judge. The decision to disqualify or recuse is not subject to appeal, but an unsuccessful recusal motion may be appealed as part of an appeal on the merits.

\section{AN OVERVIEW OF JUDICIAL DISQUALIFICATION UNDER THE QUEBEC CODE OF CIVIL PROCEDURE}

The rules governing judicial disqualification in the province of Quebec differ historically from those in other Canadian provinces because the Quebec Code of

90. StPO, supra note 59, s 24(3). 
Civil Procedure ${ }^{91}$ codifies the grounds for judicial disqualification. Luc Huppé has shown that until the 1970s, Quebec law employed a framework for determining when judges were disqualified that was quite distinct from the approach employed in the rest of Canada. Under this earlier Quebecois approach, the grounds for disqualification found in the Code of Civil Procedure were treated as the exclusive basis for judicial disqualification and were interpreted in a restrictive manner that was consistent with their origins in French law. ${ }^{92}$ These grounds were not linked conceptually to the common law concept of a reasonable apprehension of bias, though there was an obvious overlap between the enumerated grounds and situations that would be regarded as giving rise to disqualification at common law. Huppé suggests that the enactment of the Quebec Charter of Human Rights and Freedoms [Quebec Charter] in 1975, and in particular its guarantee in section 23 of "a right to a full and equal, public and fair hearing by an independent and impartial tribunal," created a conceptual tension in thinking about judicial impartiality in Quebec because the courts interpreted the concept of impartiality in section 23 in a manner that reflected the common law. ${ }^{93}$ Quebec courts began to treat the grounds for disqualification contained in the Code as non-exclusive, with the result that Quebec judges were subject to disqualification in circumstances that would give rise to a "reasonable apprehension of bias" even if these circumstances did not fall within the grounds enumerated in the Code. ${ }^{94}$

91. New Code of Civil Procedure, supra note 23. The National Assembly of Quebec enacted the new Code of Civil Procedure in February of 2014, but it was not proclaimed into force until January 1, 2016. For ease of reference, we will describe this as the "new Code of Civil Procedure." Most of the provisions dealing with judicial disqualification in the Code that were in force prior to the coming into force of the new Code were enacted in 2002, and we will describe these as the "2002 disqualification provisions." SQ 2002, c 7 [2002 disqualification provisions]. For the most part, the Code provisions dealing with judicial disqualification prior to 2002 were enacted in 1965, and we will describe these as the "1965 disqualification provisions." SC 1965, c 80 [1965 disqualification provisions].

92. Luc Huppé, "La transformation du modèle québécois de récusation des juges" (2012) 46 Revue juridique Thémis 209 at 212-19. See e.g. Kruger Inc v Kruco Inc, [1987] RDJ 622 (Qc CA) at paras 8-20, aff g on other grounds [1987] RJQ 1071 (Qc Sup Ct). On this view of the law, reasonable apprehension of bias could be asserted as a ground of appeal but was not a basis for disqualifying a judge from hearing the case at first instance.

93. Huppé, supra note 92 at 217-219. See also 2747-3174 Québec Inc v Québec (Régie des permis d'alcool), [1996] 3 SCR 919 at paras 44-45, 140 DLR (4th) 577.

94. See Droit de la Famille - 1559, [1993] RJQ 625 at paras 11-12, 21-22, 101 DLR (4th) 345 (Qc CA). 
The Code's 1965 disqualification provisions ${ }^{95}$ contained nine grounds for disqualification in section 234 and a tenth ground in section 235. Section 234 stated that "[a] judge may be recused ..." on any of the enumerated grounds whereas section 235 stated that "[a] judge is disqualified if he or his consort is interested in the action." ${ }^{\prime 6}$ Five of the grounds of disqualification addressed situations in which the judge or a close relative had a financial or other personal interest in the outcome of the litigation..$^{97}$ Two concerned situations where the judge had an association with a litigant or counsel. ${ }^{98}$ The other three concerned the judge's association with the case in a non-judicial capacity, ${ }^{99}$ judicial antagonism towards a party, ${ }^{100}$ and judicial interest in favouring a party. ${ }^{101}$

The 1965 version of the Code also codified the procedure for recusal and disqualification. Judges had an affirmative obligation to make a written declaration of facts that might lead to their disqualification. ${ }^{102}$ If a judge chose not to recuse of his or her own motion, a party could make a motion for the judge's disqualification within ten days of the judge's declaration or at any other time provided the party was diligent in raising this possibility once the relevant facts came to their attention. ${ }^{103}$ If a party made a motion that the judge be disqualified, the judge had ten days to declare whether the facts alleged were true, and then the motion would be heard by a judge other than the judge whose disqualification was being sought. ${ }^{104}$ If the motion was upheld the judge was disqualified and a new judge would be assigned; if the motion was dismissed the judge was obliged to hear the case. ${ }^{105}$ Section 242 of the Code allowed parties to waive their right to have a judge disqualified, except in situations falling under the disqualification

95. These provisions are found principally in the 1965 version of the Code. SC 1965, c 80, ss 234-42. There were, however, some relatively minor amendments between 1965 and 2002.

96. This version of s 235 was inserted in amendments to the Code of Civil Procedure in 1977. SQ 1977, c 73, s 8 [emphasis added].

97. Ibid, ss 234(1), 234(2), 234(4), 234(7), 235.

98. Ibid, ss 234(6), 234(9).

99. Ibid, s 234(3).

100. Ibid, s 234(5).

101. Ibid, s $234(8)$.

102. Ibid, s 236 .

103. Ibid, s 237.

104. Ibid, s 283.

105. Ibid, s 241 . 
requirement of section 235 of the Code, ${ }^{106}$ but also gave judges who were subject to disqualification the right to recuse themselves even if the parties did not seek their disqualification.

In 2002, the Quebec National Assembly made two significant modifications to the provisions of the Code of Civil Procedure governing judicial disqualification. First, the grounds for disqualification were modified by adding the words "in particular" to the opening words of section 234 (thereby indicating that the enumerated list of grounds of disqualification was not exhaustive) and by adding to the enumerated grounds section 234(10), pursuant to which the judge may be disqualified "if there is reasonable cause to fear that the judge will not be impartial." "107 Second, and of equal importance, the procedure for determining whether or not a judge is disqualified was altered significantly. Section 238 was modified to require a motion for the judge's disqualification to be disposed of by the judge responsible for hearing the case rather than by another judge. ${ }^{108}$ This decision was made subject to appeal in accordance with the rules governing interlocutory appeals. ${ }^{109}$ Judges were still entitled to recuse themselves of their own motion, but they had to provide a written statement of the basis for doing so in the record and the Chief Judge or Chief Justice had to be so informed. ${ }^{110}$ The legislation also added a provision that requires the clerk of the court to notify the Chief Judge or Chief Justice of any case in which the hearing is postponed because of a judge's decision to recuse himself himself or herself. ${ }^{11}$

As noted above, the provisions of the Code of Civil Procedure governing judicial disqualification have been modified again by the coming into force on 1 January 2016 of the new Code that was enacted by the National Assembly and that received Royal Assent on 20 February 2014. ${ }^{112}$ The overall thrust of the disqualification provisions of the new Code is to simplify the rules governing disqualification and make them more understandable to litigants, especially those who are self-represented, but there are a number of changes of substance. Section

106. This limitation on the right of waiver is analogous to the limitations on waiver at the federal level in the United States. 28 USC $\$ 455$ (e) permits judges to accept waiver by the parties of their right to disqualify the judge if the basis for disqualification is the general disqualification rule found in $\$ 455$ (a), but not if the basis for disqualification is one of the grounds for automatic disqualification enumerated in $\$ 455$ (b), except in unusual circumstances set out in $\$ 455(\mathrm{f})$. 28 USC, supra note $27, \$ 455$ (a)-(f).

107. 2002 disqualification provisions, supra note $91, \mathrm{~s} 47$.

108. Ibid, s 50 .

109. Ibid.

110. Ibid, s 48 (amending s 236 of the Code of Civil Procedure).

111. Ibid, s 51 (replacing s 240 of the Code of Civil Procedure).

112. SQ 2014, c 1, ss 201-205. 
201 of the new Code is analogous to section 236 of the 2002 disqualification provisions. It imposes an obligation on a judge who is aware of a basis for his or her disqualification to make a declaration to this effect and be replaced as the presiding judge and an obligation on parties who become aware of a basis for the judge's disqualification to make a declaration without delay. The significant textual difference between section 201 of the new Code and section 236 of the 2002 disqualification provisions is that the obligations under the new Code are triggered by "serious reasons to question the judge's impartiality" whereas under the 2002 provisions the obligations are engaged by awareness of a "ground of recusation." This new terminology is repeated in section 202 of the new Code, which parallels section 234 of the 2002 disqualification provisions and identifies the bases upon which a judge may be disqualified. The opening words of section 202 of the new Code are: "The following situations, among others, may be considered serious reasons for questioning a judge's impartiality and for seeking the judge's recusation." 113 Six subsections follow, which rephrase and to some extent modify the grounds of disqualification found in subsections 234(1)-234(9) of the 2002 disqualification provisions. ${ }^{114}$ Section 203 of the new Code mirrors section 235 of the 2002 disqualification provisions. It deals with situations where the judge (or the judge's spouse) has an interest in the case, and it also uses the mandatory term "is disqualified" rather than a phrase like "may be considered a basis for disqualification." The procedural regime for

113. New Code of Civil Procedure, supra note 23, s 202.

114. Ibid, ss 202(1)-(5); Code of Civil Procedure, ss 234(1)-(9). S 202(1) provides for disqualification where the judge is a spouse or close relative of one of the parties or their lawyer, thereby combining and slightly modifying ss 234(1) and 234(9) of the 2002 provisions. S 202(2) replaces s 234 (2) of the 2002 provisions in providing for disqualification where the judge is "a party to a proceeding pertaining to an issue similar to the one before the judge for determination." S 202(3) rewords part of s 234(3) of the 2002 provisions and provides for disqualification where a judges has "given advice or an opinion on the dispute" or has "previously dealt with the dispute as arbitrator or mediator." S 202(4) provides for disqualification on the basis of "the judge having represented one of the parties," thereby replacing the aspect of s 234(3) of the 2002 provisions that provided for disqualification if "the judge has acted as attorney for any of the parties ... ." S 202(5) provides for disqualification where the judge is "a shareholder or an officer of a legal person or a member of a partnership or an association or another group not endowed with juridical personality that is a party to the proceeding." This provision modifies elements of ss 234(6) and 234(7) of the 2002 provisions. Finally, s 202(6) provides for disqualification on the basis of "a serious conflict existing between the judge and one of the parties or the lawyer of one of the parties, or threats or insults having been uttered between them during the proceeding or in the year preceding the application for recusation." This provision modifies s 234(5) of the 2002 provisions. 
dealing with recusal found in sections $236-241$ of the 2002 disqualification provisions is substantially retained in sections 204 and 205 of the new Code. The new Code removes section 242, which addressed the issue of waiver, but a party's option to waive the right to seek recusal is embedded in the text of section 201.

It is noteworthy that the new Code eliminates the ground of disqualification found in subsection 234(10) of the 2002 provisions ("there is reasonable cause to fear that the judge will not be impartial") and instead positions "serious reasons for questioning a judge's impartiality" as a general organizing principle in the opening words of section $202 .{ }^{115}$ While it remains to be seen how Quebec courts will interpret these words, in our view there is a strong likelihood that they will be interpreted in a manner that is very similar to the approach to the "reasonable apprehension of bias" test taken by courts in other Canadian provinces. As noted above, the new disqualification regime is presumably designed to satisfy the impartiality requirements of section 23 of the Quebec Charter, which are based on the common law standard of impartiality. It is therefore reasonable to assume that section 202 will be interpreted in a manner that provides standards of disqualification that are at least as stringent as those required by the common law. Indeed, it is worth noting that at least some of the grounds for disqualification enumerated in subsections 202(1) - 202(6) of the new Code appear to be somewhat broader than the grounds for disqualification under the common law as it is applied in other Canadian provinces. For example, subsection 202(4) treats "the judge having represented one of the parties" as a situation that "may be considered [a] serious [reason] for questioning a judge's impartiality." At common law, the fact that a judge had represented one of the parties might be the basis for finding a "reasonable apprehension of bias," but in the absence of other considerations this rationale for disqualification would dissipate after a cooling-off period. Similarly, on its face, subsection 202(5) provides that a judge who is a shareholder of a corporation that is a party to a proceeding would be disqualified, whereas at common law there is significant authority for the proposition that a judge who owns shares in a publicly traded corporation that is a party to a proceeding is only disqualified if the outcome of the litigation could influence the value of the judge's shares. ${ }^{116}$ It is possible that the use of the term "may" in the opening words of section 202 will give Quebec judges the flexibility

115. Ibid, s 202.

116. See Ebner, supra note 32; Bernert v Absa Bank Ltd s, (2011) [2010] ZACC 28, (3) SA 92, CCT 37/10 (S Afr Const Ct), citing Ebner, supra note 32 at paras 54-57, 67-68. 
to avoid automatic disqualification in situations falling within the scope of subsections 202(4) and 202(5) that would not require recusal at common law. ${ }^{117}$

\section{POTENTIAL RULE-BASED SOLUTIONS FOR DISQUALIFICATION ISSUES IN COMMON LAW JURISDICTIONS}

The statutory regimes for judicial disqualification in the United States, Germany, and Quebec all use slightly different words to express the general principle that judges should not hear cases in which their impartiality can reasonably be called into question, and they share this principle with jurisdictions that use the common law to govern judicial disqualification. The challenge for all these jurisdictions, therefore, is to define with greater precision which types of challenges to a judge's impartiality the law will regard as "reasonable" and therefore acceptable and, correspondingly, which types of challenges will not be regarded as acceptable. Despite the admonition by common law courts that the application of the "reasonable apprehension of bias" test is fact- and context-specific, common law decisions have been successful at identifying a range of limitations on the types of challenges to a judge's impartiality that are likely to succeed. Indeed, the English Court of Appeal's decision in Locabail is best understood as a self-conscious effort on the part of the court to reassert the boundaries for successful challenges to the perception of judicial impartiality in the wake of the House of Lords decision in Pinochet. ${ }^{118}$ Statutory jurisdictions such as Germany, the United States, and, to a lesser extent, Quebec go beyond articulating a statutory standard of reasonable apprehension of bias to make rules about situations that do and do not warrant recusal.

We argue in this part of the article that there would be merit in using rules rather than common law decisions to establish the boundaries for successful challenges to judicial impartiality in a number of areas. We do not suggest that it would be appropriate for common law jurisdictions to simply copy the rules employed in the United States or Germany or even for other Canadian provinces

117. By way of analogy, in Dufour v 99516 Canada Inc, the Quebec Court of Appeal focused on whether the trial judge's relationship with one of the parties would give rise to a reasonable apprehension of bias, and decided that it would not, rather than focusing on whether the relationship was one that strictly fell within the scope of one of the grounds enumerated under s 234 of the Code's 1965 disqualification provisions. Dufour, supra note 23; 1965 disqualification provisions, supra note 91, s 234.

118. See Kate Malleson, "Safeguarding Judicial Impartiality" (2002) 22 Legal Studies 53 at $53-54,62$. 
to adopt the Quebec regime. Further, any rules should be specific to the court or administrative tribunal. As the German rules illustrate, the regulatory regime should be tailored to the jurisdictional scope of the court. While there are common themes in all the statutory regimes, there are also significant differences among them both at a structural level and in matters of detail. These differences, as well as the similarities, are instructive as we consider the role that rules might be able to play in supplementing common law principles governing judicial disqualification.

In our view, there are several reasons to believe that statutory rules will be helpful in supplementing the common law "reasonable apprehension of bias" test. The first is that, as our empirical research suggests, decisional law typically under-represents the instances in which judges recuse themselves, so the case law is likely to give at best a partial view of existing judicial practice. Second, there is reason to believe that informal practices concerning recusal are not particularly well understood by many members of the judiciary, with the result that they are likely to be applied inconsistently. This can cause unnecessary redistribution of workload among judges and potentially unnecessary delay to parties. Both might be alleviated if a formal set of standards were articulated in the form of a rule. Third, reliance on ill-understood and inconsistently applied informal understandings of when it is and is not appropriate for a judge to be recused in marginal situations can cause difficulty for parties and their counsel. The existence of clearer rules governing when a judge is or is not disqualified may prevent counsel from wasting time advancing arguments for recusal when the application has no reasonable chance of success and may at the same time increase the confidence of parties and counsel in advancing valid objections to the judge's participation. Fourth, there are, at least in some circumstances, compelling reasons to create procedural rules that give judges the explicit authority to refer the decision about whether or not disqualification is required to another judge. Fifth, there are circumstances in which considerations of efficiency or other requirements of our system of adjudication enable judges to sit notwithstanding what appears to be an objective basis for arguing that the judge is predisposed in one manner or another. One example is situations where arguments are raised that a judge's advocacy or writings prior to judicial appointment are indicative of partiality. ${ }^{119}$ In at least some of these situations it may be helpful for a judge to be able to point to a rule authorizing him or her to sit, rather than to have to explain to an objecting party that there is no reasonable basis for perceiving that the judge is anything but impartial. Finally, there are some situations in which 
it may be useful to establish a bright-line standard for when disqualification is required, since the choice of any particular place to draw the line is somewhat arbitrary. Requiring individual judges to guess where that line ought to be drawn on the basis of little or no information places them in a difficult if not impossible situation. The best example of this type of situation is the cooling-off period for judges to hear cases argued by members of their former law firms or involving their former clients. As demonstrated by the experience of the German Constitutional Court and for reasons discussed in more detail below, there are good grounds for thinking that a cooling-off period is desirable but it is not obvious what the appropriate length of that cooling-off period ought to be, and a formal rule is both a more effective and a more transparent way of making that determination than an informal local practice.

As indicated at the outset of the article, we believe that there are three substantive areas and one procedural area in which rules would be particularly well-suited for giving guidance on judicial disqualification. They are: (1) professional relationships between justice personnel and litigation participants; (2) prior judicial consideration in the cause or in related litigation; (3) extrajudicial writings suggesting a predisposition; and (4) procedures for recusal motions. We will address each in turn. We refrain from offering draft rules because they need to be tailored to each court or tribunal, but we offer what might be thought of as general drafting instructions at the end of each section.

\section{A. PROFESSIONAL RELATIONSHIPS WITH FORMER COLLEAGUES AND CLIENTS}

Since all Canadian judges were once lawyers, ${ }^{120}$ it is normal that they will have professional relationships with former clients and with former colleagues from their law firms. Some of these relationships may be sufficiently close that a judge would never feel comfortable hearing a case involving the other person-for example, a case argued by a former colleague who is a close personal friend or involving a client with whom the judge worked closely for years in his or her capacity as a lawyer. In addition, the Canadian jurisprudence strongly supports the view that if a judge was personally involved in a matter during his or her

120. This is a common feature of judicial systems based on the English model, but it is not a universal feature of legal systems around the world. For example, the judicial system in Germany and other European countries draws its members from persons who were trained as adjudicators rather than from the ranks of the legal profession. 
career as a lawyer, the judge should not sit on a case that involves that matter. ${ }^{121}$ This is not an ironclad rule since the Supreme Court of Canada has concluded that if the matter was sufficiently far in the past and the judge's involvement sufficiently tangential that he or she has no recollection of it, it can be permissible for the judge to sit. ${ }^{122}$ As noted in Part I, above, the advice given to Canadian judges is that the judge should adopt "a 'cooling-off period, often established by local tradition at 2, 3 or 5 years and in any event at least as long as there is any indebtedness between the firm and the judge" in situations where the professional relationship with a former colleague or client is not one that places the judge in a conflict of interest. In this context, conflicts of interest are confined to situations where the judge was personally involved with the matter in dispute, the firm was involved in the dispute while the judge was still a member of the firm, or close personal relationships were in play. ${ }^{123}$

As discussed earlier, the problem with a cooling-off period established by local tradition is that the tradition may not be passed on effectively to judges, and it is even less likely that counsel and self-represented litigants will be aware of the tradition. The fact that local tradition is variously described as setting the cooling-off period at two, three, or five years suggests that the choice of any particular time frame is less important than the fact that there be a shared understanding of what the time frame is, and this in our view lends itself to being established through a rule.

None of the German, Quebecois, or American federal disqualification rules provide for cooling-off periods, and they take quite different approaches to disqualification based on relationships with former clients and professional colleagues. Subsection 234(3) of the 2002 disqualification provisions of the Quebec Code of Civil Procedure identifies the fact that "the judge has acted for one of the parties" as a potential ground of disqualification without reference

121. See e.g. Committee for Justice and Liberty $v$ Canada (National Energy Board), [1978] 1 SCR 369, 68 DLR (3d) 716; $R v$ Catcheway, 2000 SCC 33, [2001] SCR 838; Barrett v Glynn, 2001 NFCA 70, 207 Nfld \& PEIR 213.

122. See Wewaykum, supra note 3.

123. Canadian Judicial Council, supra note 10 at 52 . While the choice of any particular cooling-off period is somewhat arbitrary, our preference is for a period at the shorter end rather than the longer end of the range. In circumstances in which a judge harbours lingering doubts about his or her ability to be impartial in adjudicating a matter involving a former colleague or client, it is always open for the judge to recuse notwithstanding the fact that the cooling-off period has elapsed. On the other hand, a judge is not in a position to abridge the cooling-off period if the judge is satisfied that there is no actual basis for concern about his or her ability to adjudicate impartiality, since this would be inconsistent with the rationale for establishing the cooling-off period in the first place. 
to the passage of time and without qualifying the lawyer-client relationship to the matter currently before the court, ${ }^{124}$ and this approach is continued in subsection 202(4) of the new Code. Neither the 2002 provisions nor the new Code lists the relationship with members of the judge's former law firm as an explicit ground of disqualification. ${ }^{125}$ While German disqualification rules are absolute with respect to adjudicating matters where the judge has acted as counsel, they are silent on whether recusal is necessary if a former client or colleague appears before the judge on an unrelated matter. For example, criminal court judges are disqualified if they have "acted in the case as an official of the public prosecution office, as a police officer, as attorney of the aggrieved person or as defence counsel." 126 Similarly, a civil court judge is barred in "all matters in which he was appointed as attorney of record or as a person providing assistance to a party, or in which he is or was authorised to make an appearance as a legal representative of a party." ${ }^{27}$ By implication through omission, German judges are not barred from hearing cases brought by, against, or involving a former client in an unrelated matter at any time. As is clearly apparent from our discussion of the jurisprudence of the Constitutional Court, the mere fact that a German judge had a prior association with a law firm that is now representing a client before the judge is not, without more, reason for recusal. As American federal practice does not explicitly disqualify judges for hearing cases involving former clients as distinct from hearing cases in which they were personally involved in a non-judicial capacity, these jurisdictions offer somewhat limited guidance as to the precise content of a rule governing cooling-off periods. ${ }^{128}$ Similarly, American federal rules governing disqualification because of a judge's association with

124. 2002 disqualification provisions, supra note 91, s 234(3). This section also lists the fact that "the judge has given advice on the matter in dispute" as a potential ground of disqualification, which suggests that the fact that the judge has acted for one of the parties in the past is a ground of disqualification regardless of whether that representation took place in the context of the matter currently before the court.

125. Ibid, s 234(9)-(10). The relationship with lawyers is a ground of disqualification under s 234(9) of the 2002 disqualification provisions if "the judge is the spouse of or is related or allied to the attorney or counsel or to the partner of any of them" but the Code makes no reference to former professional colleagues and this relationship would have to be assessed under the general ground of disqualification found in s 234(10). Section 202(1) of the new Code takes a similar approach to disqualification based on the judge's relationship to a lawyer of one of the parties. New Code of Civil Procedure, supra note 23, s 202(1).

126. StPO, supra note 59, s 22 [emphasis added].

127. German Code of Civil Procedure [ZPO], s 41(4), online: <https://www.gesetze-im-internet.de/ englisch_zpo/englisch_zpo.html>.

128. See e.g. 28 USC, supra note $27, \$ 455$ (b)(2)-(3); StPO, supra note 59, ss 22(4)-(5); ibid, ss 41(4)-(6). 
a lawyer with whom the judge previously practiced refer only to situations in which the "lawyer with whom the judge previously practiced law served during such association as a lawyer concerning the matter." 129 On the other hand, the provisions of subsection 170.1(2)(B) of the California Code of Civil Procedure offer a model for a two-year cooling-off period that could be adopted by rule in Canada or in other common law jurisdictions.

In sum, we recommend an express rule that judges may hear cases involving lawyers in their former law firms as long as there is no further indebtedness and more than two years have passed since the appointment of the judge. Similarly, we recommend a two-year cooling-off period for former clients in unrelated matters.

\section{B. PRIOR JUDICIAL INVOLVEMENT WITH LITIGANTS}

One of the areas of recusal law described by judges as raising the most difficult issues is what is sometimes described as the repeat customer phenomenon. For purposes of Canadian law, two situations need to be distinguished: (1) unrelated prior litigation and (2) related litigation or interlocutory matters in the same litigation.

As regards the first situation, in none of the jurisdictions under consideration is the mere fact that the judge has encountered one of the litigants in the course of presiding over another, unrelated matter a basis for disqualification. Canadian case law suggests that greater care must be taken where a judge has made an adverse credibility finding against a party in a previous case, but even in these circumstances disqualification is not required in all cases. Rather, the issue is whether the findings were expressed in sufficiently strong terms that a reasonable person would doubt the ability of the judge to adjudicate the present cases fairly upon the evidence adduced before him or her in a subsequent unrelated proceeding.

The second situation covers previous encounters with litigants in related litigation or other stages of the same litigation. Again, it is common ground among the jurisdictions under consideration that the mere fact that a judge was involved in some prior stage of the proceeding does not give rise to a reasonable apprehension of bias. Examples include breach hearings following sentencing

129. 28 USC, supra note $27, \$ 455(\mathrm{~b})(2)$. 
with conditions, bail hearings followed by the trial on the merits, preliminary motions, voir dire rulings, and case-managed litigation. ${ }^{130}$

In Canada, the jurisprudence establishes that a judge may sit even if the judge found against a party in a prior unrelated proceeding or on an interlocutory issue. In our view, the basic rule that a prior encounter between judge and litigant does not, without more, warrant recusal could easily be codified. Its extension, that an adverse ruling in an interlocutory issue also does not warrant recusal, may be more problematic. This is because the manner in which the adverse ruling is expressed influences the recusal analysis. Whether judicial commentary strays into the forbidden zone is too contextual and nuanced to be readily captured in a bright-line rule.

As regards prior judicial dealings in the same or related proceedings, at least three distinct problems arise with some frequency. The first is the perception of the litigant, particularly one who is self-represented, that any prior finding of a judge vis-à-vis that litigant is prejudicial in terms of the ultimate outcome of the litigation. The second is the concern that evidence that does not form part of the record will contaminate the proceeding. The third is that remarks made by the judge in the context of fact findings or characterizations of the argument advanced by counsel or the litigant are seen as prejudging the matter. The first concern is particularly susceptible to bright-line rule making.

Efficient use of judicial resources generally suggests that a judge who is already familiar with the matter should be the judge dealing with it in its entirety. Additionally, the risk for inconsistent fact findings is reduced if only one judge remains seized of the matter. These reasons are sufficiently important that the feelings of the litigants will usually have to give way to them. Thus, the question is rarely whether a judge should be recused merely because he or she has been involved in the matter before, but how best to communicate to litigants that, despite their misgivings, the proper administration of justice demands that the judge continue to sit. One of the advantages of a rule-based approach is that the judge can point to the rule in explaining to the litigant, particularly the self-represented litigant, that recusal is not appropriate.

130. The phenomenon of judicial dispute resolution (including settlement conferencing and mediation) should be distinguished for these purposes from case management. In some jurisdictions, the rules structuring this phenomenon forbid judges who have engaged in dispute resolution efforts from subsequently adjudicating the matter if no settlement is reached. See e.g. British Columbia Supreme Court Family Rules, BC Reg 169/2009, ss 7-1(17), 7-2(3); New Code of Civil Procedure, supra note 23, s 165. Other jurisdictions permit the judge to continue and adjudicate the case, but only with the agreement of the judge and all of the parties. (See, e.g. Alberta Rules of Court, Alta Reg 124/2010, s 4.21.) 
In all three jurisdictions we have examined, the sole blanket exception to the general rule that a judge may sit in cases despite prior judicial involvement is the participation of a judge in an appellate consideration of his or her own decision. In the German context, the specific mention of this exception makes clear that other forms of prior judicial involvement do not attract disqualification. The equivalent limitation is also codified at the federal level in the United States ${ }^{131}$ and in a number of Canadian jurisdictions. ${ }^{132}$ Nevertheless, the leading United States Supreme Court decision on the question of whether prior judicial involvement in a case attracts disqualification, Liteky $v$ United States, ${ }^{133}$ does not rely on this fact as a reason for permitting judges to sit in cases of prior judicial involvement other than one's own appeal, and we are not aware of any Canadian case that relies on comparable Canadian statutes in support of this proposition. This may suggest that the place of codification is important for its interpretation. In Germany, the bar against considering one's own decision at the appellate level is included in the general rules surrounding disqualification. In Canada, the same rules are dispersed through, inter alia, rules of court, the Criminal Code, and various enabling statutes establishing appellate courts. Section 551.1 of the Criminal Code provides that "the appointment of a judge as the case management judge does not prevent him or her from becoming the judge who hears the evidence on the merits," while section 551.4 provides for the procedure to be applied when the case management judge is also the trial judge. This recent amendment to the Criminal Code is a good example of how Canadian statute law already includes some rules that clarify the circumstances when a judge does not need to recuse. ${ }^{134}$ Similarly, British Columbia's family court rules allow the case management judge to remain seized of further applications in the cause but preclude the settlement conference judge from presiding over the trial. ${ }^{135}$

In short, we recommend enactment of an express rule that prior judicial involvement with a litigant is not, without more, a basis for recusal regardless of whether the litigation is related or not.

131. 28 USC, supra note $27, \S 47$. The section reads, "No judge shall hear or determine an appeal from the decision of a case or issue tried by him."

132. See e.g. Supreme Court Act, RSC 1985, c S-26, s 28(1); New Brunswick Judicature Act, RSNB 1973, c J-2, s 8(7); Alberta Court of Appeal Act, RSA, c C-30, s 11.

133. (1994) 510 US 540, 114 S Ct 1147.

134. SC 2011, c 16, s 4 .

135. British Columbia Supreme Court Family Rules, supra note 130. S 165 of the new Code of Civil Procedure also indicates that a judge who presides over a settlement conference can take appropriate case management measures but may not "subsequently try the case or decide any incidental application." New Code of Civil Procedure, supra note 23, s 165. 


\section{EXTRAJUDICIAL WRITINGS}

Canadian courts have generally been reluctant to disqualify judges simply because of their extrajudicial writings, be they related to advocacy, advice to government, political activity, or academic commentary. A prominent example of this reluctance is the decision of Justice Bastarache of the Supreme Court of Canada in Arsenault-Cameron. ${ }^{136}$ The case involved minority language rights and Justice Bastarache had written extensively on the issue when he was a law professor. He had also been counsel for minority language rights groups prior to his appointment to the bench. When the Prince Edward Island case came to the Court, counsel for the province brought a motion for his recusal. The Court took the opportunity to clarify the procedure appropriate for recusal and denied the motion. The decision is not only in line with Canadian jurisprudence but also with the practice of comparator courts of last resort. ${ }^{137}$ It is nevertheless easy to see why counsel might have been concerned. As in the situation of the self-represented litigant re-encountering a judge, the issue is not so much whether recusal is appropriate but how to communicate that the judge should continue to sit. One of the animating reasons for adopting a "reasonable apprehension of bias" test in preference over requiring proof of actual bias is that both the presence and the absence of an open mind are difficult to prove. There is a reason why the issue arises most commonly in appellate and constitutional courts. These courts have tended to recruit more routinely from the professoriate than do the trial courts, although recent Canadian experience seems to suggest an increased trend towards appointing law professors to provincial courts. ${ }^{138}$

In all of these cases, then, there is reason to consider whether bright-line rules might be better suited to promote confidence in the justice system and give

136. Arsenault-Cameron v Prince Edward Island, [1999] 3 SCR 851, 201 Nfld \& PEIR 1; Arsenault-Cameron v Prince Edward Island, 2000 SCC 1, [2000] 1 SCR 3.

137. In a recent decision, the Supreme Court confirmed that in addition to extrajudicial writing, judicial involvement in community organizations does not generally give rise to a reasonable apprehension of bias. Yukon Francophone School Board, Education Area \#23v Yukon (Attorney General), 2015 SCC 25 at para 62, [2015] 2 SCR 282.

138. It is interesting to note that in an article entitled "Some Problems with Extrajudicial Writing," Susan Bartie and John Gava argue that judges should not engage in scholarly writing on legal topics after they have been appointed to the bench out of a concern that such writings will give rise to a reasonable apprehension that the judge has predetermined legal issues that may arise in a case that comes before the judge for adjudication. "Some Problems with Extrajudicial Writing” (2012) 34 Sydney L Rev 637. Bartie and Gava draw a distinction between scholarly writing that takes place before the judge's appointment, which should not reasonably be treated as giving rise to a basis for disqualification, and the extrajudicial writings of sitting judges (ibid at 653-54). 
comfort to litigants, or at least avoid unnecessary and ultimately unsuccessful recusal motions. Inspiration might be taken from the German Constitutional Court, despite the fact that the institutional practices of that court are greatly at variance with the Canadian situation. As discussed in Part III, above, judges are appointed to the court for a single tenure of twelve years, they overwhelmingly come from the legal academy, and they routinely continue to participate in academic conferences and publications throughout their judicial tenure. Given that institutional design, it is foreseeable that the situation in Arsenault-Cameron would occur with much higher frequency in that court absent a statutory rule to the contrary. The Constitutional Court Act therefore usefully provides that neither advice to government, nor involvement in the drafting process of legislation, nor academic writing gives rise to a reasonable apprehension of bias.

We recommend that rules of court provide that neither writing nor speech making prior to judicial appointment disqualify a judge, even if he or she advocates a position on a contentious issue. We note that this would not relieve judges of the obligation to consider whether they are able to approach with an open mind an issue they have spoken or written about.

\section{PROCEDURAL RULES}

In most parts of Canada, there is no special procedure by which parties may seek the disqualification of a judge. ${ }^{139}$ It is common for judges to recuse themselves of their own motion if they believe that they are disqualified, and our research suggests that this is the most common procedural context in which recusal decisions are made. ${ }^{140}$ If a party wishes to seek a judge's recusal, the normal practice is for a party to make a motion using the ordinary rules of motion practice. ${ }^{141}$ It is also relatively common for judges who are unsure about whether or not they should recuse themselves to seek submissions from the parties. ${ }^{142}$

139. As noted above, Quebec is exceptional in this respect.

140. See Bryden \& Hughes, "Tip of the Iceberg," supra note 4 at 576-77.

141. See Bryden, "Legal Principles," supra note 6 at 590-94. Geoffrey Lester has suggested that a preferable practice would be for counsel to make an informal application from the bar table with appropriate supporting materials, but he acknowledges that the use of a motion is the common practice. Geoffrey Lester, "Disqualifying Judges for Bias and Reasonable Apprehension of Bias: Some Problems of Practice and Procedure" (2001) 24 Advocates Q 326 at 342-46.

142. See e.g., Lambert, supra note 47. The New Brunswick Court of Appeal has advised that, in these situations, the proper practice is for the judge to seek submissions and render the decision personally rather than to seek a waiver from the parties or indicate that the judge will automatically recuse if the party raises an objection. 
While this procedure works tolerably well, it does present certain difficulties that could be addressed through the use of procedural rules.

The first difficulty concerns the fact that the judge whose impartiality is being questioned makes the decision about whether or not he or she is disqualified. There are a number of practical reasons why it may be desirable in some circumstances to have the judge whose disqualification is at issue make the determination, at least at first instance. One is that the judge is in the best position to know subjectively if there is a real basis for concern about his or her ability to decide impartially, and in those situations the judge ought to be in a position to decide that it is inappropriate for him or her to sit. ${ }^{143} \mathrm{~A}$ second reason is that automatically referring the matter to another judge might encourage parties to make unmeritorious applications for tactical reasons, for example to create delay. A third is that there are situations in which the basis for disqualification arises unexpectedly, for example if a judge recognizes a social relationship with a witness when the witness first appears in court partway through a lengthy hearing. Referral in these circumstances may cause delay that is not in the best interests of either party. As we indicated in Part IV, above, prior to 2002 sections 238 - 41 of the Quebec Code of Civil Procedure required applications for recusal to be heard by a different judge than the judge whose recusal was being sought, but when the National Assembly amended the rules governing recusal in 2002, it established a procedural regime in which motions for recusal are heard by the judge seized of the case. ${ }^{144}$

143. This view is consistent with the conclusions of Canadian Judicial Council in its report of a complaint concerning the recusal of Justice Jean-Guy Boilard in the midst of a long and complicated criminal trial after he received a letter from the Canadian Judicial Council criticizing his treatment of one of the lawyers in a related case. The Council observed that it is the individual responsibility of every judge to determine whether there are circumstances that prevent him or her from continuing to hear a case, and in the absence of evidence of bad faith, there is no basis for criticism of that decision. Canadian Judicial Council, Report of the Canadian Judicial Council to the Minister of Justice of Canada under s. 65(1) of the Judges Act concerning Mr. Justice Jean-Guy Boilard of the Superior Court of Quebec (Ottawa: Canadian Judicial Council, 2003) at 3-4, online: <http://www.cjc-ccm.gc.ca/cmslib/general/ conduct_inq_boilard_ReportIC_200312_en.pdf>.

144. SQ 2007, c 7, ss 48-51. Huppé has observed that this procedural change was based on a recommendation of the Comité de Révision de la Procédure Civile in order to avoid improper interference with judicial independence. Huppé, supra note 92 at 227-34. Huppé argues, in our view correctly, that the protection of judicial independence does not require that a judge who is the subject of a motion seeking his or her disqualification be obliged to decide the motion personally. In our view, there are practical reasons why it is appropriate for the judge to be empowered to do so, but this should not prevent the creation of rules that empower the judge to transfer the motion to another judge for adjudication. 
At the same time, many commentators, ${ }^{145}$ including some judges, ${ }^{146}$ have noted the awkwardness of asking the judge whose impartiality is called into question to adjudicate this issue. This awkwardness is particularly apparent where the challenge to the judge's impartiality is based on things the judge has said or done, either during the course of the hearing or outside of it, that give rise to a concern on the part of a party that the judge is not capable of deciding the case impartially. In our view, it would be helpful to give judges the explicit authority to refer the matter to another judge, especially in such circumstances. We are mindful of the advantages of regimes that require all recusal motions to be heard by someone other than the judge whose recusal is sought, at least if the judge does not recuse himself or herself right away on receiving the motion, but it seems to us that in most situations, the reasons described above for having the judge whose recusal is sought make the determination are persuasive. Giving the judge who is the subject of the recusal application the discretion to refer the matter to another judge should be sufficient to capture those instances where the interests of justice would be better served by having another judge make the decision.

The other procedural issue that has raised some difficulties in Canada is the question of who makes the decision on an application to disqualify one member of a multi-member panel. While there has been some unevenness in Canadian practice over time, ${ }^{147}$ the current view is that the judge whose recusal is sought makes the decision. ${ }^{148}$ The more difficult question is whether this decision is subject to review by the other members of the panel, and, if not, what steps the other members of the panel should take if they disagree with the other judge's decision not to recuse. In SOS-Save Our St. Clair Inc. v Toronto (City), ${ }^{149}$ the majority of the panel decided that, based on their concerns regarding the decision of the third member of the panel not to recuse himself, they would withdraw, thereby requiring the constitution of a new panel to hear the matter in dispute. While this type of unfortunate situation is unlikely to arise very often, it seems

145. See e.g. Bassett \& Perschbacher, "Elusive Goal”, supra note 29 at 203-207, 213-14; Amanda Frost, "Keeping Up Appearances: A Process-Oriented Approach to Judicial Recusal" (2004-2005) 53 U Kan L Rev 531 at 571-72, 583-87.

146. See Ebner, supra note 32 at paras 74 (per Gleeson CJ, McHugh, Gummow \& Hayne JJ), 185 (per Callinan J); Sir Anthony Mason, "Judicial Disqualification for Bias or Apprehended Bias and the Problem of Appellate Review” (1998) 1 Constitutional Law and Policy Review 21.

147. See Bryden, "Legal Principles," supra note 6 at 594-95.

148. See SOS-Save Our St Clair Inc v Toronto (City) (2005), 78 OR (3d) 331at paras 19-20, 115-18, 261 DLR (4th) 727 (Ont Div Ct) (per Greer, E. Macdonald \& Matlow JJ) [SOS-Save Our St Clair Inc]; c.f. CEP, Local 60N v Abitibi Consolidated Inc, 2008 NLCA 4 at para 35, 273 Nfld \& PEIR 17.

149. SOS-Save Our St Clair Inc, ibid at 148. 
to us that it would be preferable to have procedural rules that would give both judges and parties guidance on how to address recusal applications when dealing with multi-member panels.

One possibility would be to maintain the current practice that would require the judge whose recusal is being sought to make the decision but add a right of review of that decision by the other members of the panel. A second possibility, which would be our preferred option, is to make a rule that the recusal of any panel member must be addressed by the entire panel. ${ }^{150} \mathrm{~A}$ third possibility would be to adopt the German practice of having all of the members of the panel except the judge whose recusal is being sought hear the motion. ${ }^{151}$ We prefer the option of a rule that the whole panel hear the matter because it enables the parties to have the benefit of the views of the entire panel on what is, in essence, a legal question. Presumably if the judge in question is uncomfortable about being involved in the decision it would be open to him or her to recuse himself or herself on the motion and let the other members of the panel decide, but as we have suggested above, in most situations there are reasons why it is appropriate that the judge whose recusal is being sought have an opportunity to participate in the decision, even if that judge does not have the final say in the matter.

In our view, express procedural rules included in the rules of court would be preferable to the current ad hoc approach. Reasonable arguments can be made for a variety of approaches, as the comparator jurisdictions illustrate. Our recommendation is to grant judges the express power to refer a recusal motion. For multi-member panels, we recommend that the panel, not only the judge with respect to whom a reasonable apprehension of bias is alleged, should entertain the motion. The judge should have the right to recuse himself or herself from the decision on the motion.

150. This approach was adopted in admittedly unusual circumstances by the South African Constitutional Court. See President of the Republic of South Africa v South African Rugby Football Union [1999] ZACC 9, 1999 (4) SA 147 (S Afr Const Ct). In that case, the applicants sought the recusal of five of the ten members of the Court, and further allegations and complaints were made about all of the members of the Court. With the agreement of counsel, the entire Court heard the motion for recusal.

151. This is the approach used by the New Zealand Supreme Court in Siemer v Heron. Siemer v Heron, [2011] NZSC 116, [2012] 1 NZLR 293. The applicant sought an order that two members of the Court not sit on the case on the basis of an apparent bias against him, and the other three members of the Court heard and dismissed the application. 


\section{CONCLUSION}

There are good reasons why the "reasonable apprehension of bias" test is context-specific and why it may not be possible to supplant it completely with a comprehensive set of rules governing judicial disqualification. Nevertheless, the experience in comparator jurisdictions suggests that there may be a place for recusal rules in some circumstances. The animating reasons for urging a (modest) resort to a rule-based approach are grounded in efficiency, legitimacy, and access to justice.

The current case-based approach serves Canadian law well in novel situations and in cases where only a fulsome review and careful weighing of all the facts permits a determination whether a judge should recuse. However, many situations inviting bias considerations are commonplace. Empirical research has shown that resort to case law in these situations can be problematic because the jurisprudence does not compel a particular outcome and because the jurisprudence is slanted towards explaining why a judge should sit while most decisions to recuse are invisible. Even in situations where the jurisprudence is clear, the outcome is often difficult to communicate credibly to litigants. This problem is aggravated for self-represented litigants.

In this article, we have identified four situations where it would be productive to employ rules to clarify some marginal situations in which it is difficult to determine when it is, and is not, appropriate for judges to sit. We think rules would be of benefit to judges and the parties appearing before them in relation to professional relationships with former colleagues and clients, prior judicial involvement with litigants, extrajudicial writings, and procedures governing motions for recusal.

Clarifying the rules surrounding professional relationships and prior judicial involvement, and rendering them visible to counsel and self-represented litigants, would make recusal decisions more efficient, avoid unnecessary delays, and tend to legitimate recusal decisions in the eyes of litigants. The law on extrajudicial writings in Canada is clear enough, but judges still find themselves having to explain why they should sit despite having written on an issue now before the court. This is unnecessarily stressful for all participants. A rule codifying the existing law would be helpful. Finally, the Canadian literature and the literature in the comparator jurisdictions confirm that the question of who should decide recusal is the source of considerable anxiety for judges and litigants alike. The Canadian rule that the judge whose recusal is sought should decide is sound in most circumstances. However, there are cases where a fresh set of eyes would 
give comfort to litigants, counsel, and judges. Granting judges the power to refer the decision would allow for a case-by-case weighing of concerns for efficiency and legitimacy.

We do not exclude the possibility that there may be other areas in which rules would be helpful, but it seems to us that in an area where constitutional considerations lie very close to the surface it may be appropriate to begin with a relatively conservative approach to the use of rules to clarify the boundaries of judicial disqualification. 